Article

\title{
Novel Lytic Enzyme of Prophage Origin from Clostridium botulinum E3 Strain Alaska E43 with Bactericidal Activity against Clostridial Cells
}

\author{
Agnieszka Morzywolek 1,+, Magdalena Plotka 1,*,+D, Anna-Karina Kaczorowska ${ }^{\mathbb{D}}$, Monika Szadkowska ${ }^{1}$,

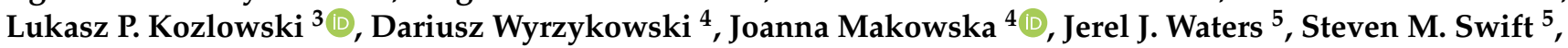 \\ David M. Donovan ${ }^{5}$ and Tadeusz Kaczorowski ${ }^{1, *}$
}

1 Laboratory of Extremophiles Biology, Department of Microbiology, Faculty of Biology, University of Gdansk, 80-822 Gdansk, Poland; a.morzywolek@gmail.com (A.M.); monika.szadkowska@phdstud.ug.edu.pl (M.S.)

2 Collection of Plasmids and Microorganisms, Faculty of Biology, University of Gdansk, 80-308 Gdansk, Poland; anna.kaczorowska@ug.edu.pl

3 Institute of Informatics, Faculty of Mathematics, Informatics and Mechanics, University of Warsaw, 02-097 Warsaw, Poland; lukaskoz@mimuw.edu.pl

4 Department of General and Inorganic Chemistry, Faculty of Chemistry, University of Gdansk, 80-308 Gdansk, Poland; dariusz.wyrzykowski@ug.edu.pl (D.W.); joanna.makowska@ug.edu.pl (J.M.)

5 Animal Biosciences and Biotechnology Laboratory, ARS, NEA, USDA, Beltsville, MD 20705-2350, USA;

check for updates

Citation: Morzywolek, A.; Plotka, M.; Kaczorowska, A.-K.; Szadkowska, M.; Kozlowski, L.P.; Wyrzykowski, D.; Makowska, J.; Waters, J.J.; Swift, S.M.; Donovan, D.M.; et al. Novel Lytic Enzyme of Prophage Origin from Clostridium botulinum E3 Strain Alaska E43 with Bactericidal Activity against Clostridial Cells. Int. J. Mol. Sci. 2021, 22, 9536. https://doi.org/ $10.3390 /$ ijms 22179536

Academic Editors: Alexande Baykov and Georg A. Sprenger

Received: 26 May 2021

Accepted: 31 August 2021

Published: 2 September 2021

Publisher's Note: MDPI stays neutral with regard to jurisdictional claims in published maps and institutional affiliations.

Copyright: (C) 2021 by the authors Licensee MDPI, Basel, Switzerland. This article is an open access article distributed under the terms and conditions of the Creative Commons Attribution (CC BY) license (https:/ / creativecommons.org/licenses/by/ $4.0 /)$. renovatebio.jerelwaters@gmail.com (J.J.W.); sswift@contrafect.com (S.M.S.); ddonovan0@yahoo.com (D.M.D.)

* Correspondence: magdalena.plotka@ug.edu.pl (M.P.); tadeusz.kaczorowski@ug.edu.pl (T.K.)

$\dagger$ Equal contribution.

Abstract: Clostridium botulinum is a Gram-positive, anaerobic, spore-forming bacterium capable of producing botulinum toxin and responsible for botulism of humans and animals. Phage-encoded enzymes called endolysins, which can lyse bacteria when exposed externally, have potential as agents to combat bacteria of the genus Clostridium. Bioinformatics analysis revealed in the genomes of several Clostridium species genes encoding putative $N$-acetylmuramoyl-L-alanine amidases with anti-clostridial potential. One such enzyme, designated as LysB (224-aa), from the prophage of C. botulinum E3 strain Alaska E43 was chosen for further analysis. The recombinant 27,726 Da protein was expressed and purified from E. coli Tuner(DE3) with a yield of $37.5 \mathrm{mg}$ per $1 \mathrm{~L}$ of cell culture. Size-exclusion chromatography and analytical ultracentrifugation experiments showed that the protein is dimeric in solution. Bioinformatics analysis and results of site-directed mutagenesis studies imply that five residues, namely $\mathrm{H} 25$, Y54, H126, S132, and C134, form the catalytic center of the enzyme. Twelve other residues, namely M13, H43, N47, G48, W49, A50, L73, A75, H76, Q78, N81, and Y182, were predicted to be involved in anchoring the protein to the lipoteichoic acid, a significant component of the Gram-positive bacterial cell wall. The LysB enzyme demonstrated lytic activity against bacteria belonging to the genera Clostridium, Bacillus, Staphylococcus, and Deinococcus, but did not lyse Gram-negative bacteria. Optimal lytic activity of LysB occurred between pH 4.0 and 7.5 in the absence of $\mathrm{NaCl}$. This work presents the first characterization of an endolysin derived from a C. botulinum Group II prophage, which can potentially be used to control this important pathogen.

Keywords: $N$-acetylmuramoyl-L-alanine amidase; Clostridium botulinum; endolysin; prophage; lipoteichoic acid

\section{Introduction}

Clostridium botulinum is an anaerobic, Gram-positive, spore-forming bacterium found in soil and water that causes botulism, a severe neuroparalytic disease affecting humans and animals [1]. Botulism typically results from ingestion of food containing botulinum neurotoxin (BoNT) secreted by vegetative clostridia. C. botulinum produces seven serotypes of botulinal neurotoxins, types $\mathrm{A}-\mathrm{G}$, divided into more than 40 different subtypes, which 
are the most lethal toxins known today (as little as $30 \mathrm{ng}$ is sufficient to cause illness in adult humans by the oral route) [2]. Human botulism is caused mainly by toxin types A, B, $\mathrm{E}$, and rarely $\mathrm{F}$, while types $\mathrm{C}$ and $\mathrm{D}$ are associated with animal botulism [3]. Type A of BoNT causes the most prolonged and most severe forms of botulism, while BoNT type $\mathrm{E}$ leads to shorter duration symptoms, and BoNT type B results in mild forms of botulism [4].

Four distinct phenotypic groups (I-IV) of C. botulinum are recognized. C. botulinum Groups I and II are primarily responsible for human botulism, the most frequent form of botulism in the European Union [5]. C. botulinum Group I has minimum and optimum growth temperatures of $12{ }^{\circ} \mathrm{C}$ and $37^{\circ} \mathrm{C}$, respectively. Spores formed by strains of this group are highly heat-resistant. Treatment of $121{ }^{\circ} \mathrm{C}$ for $3 \mathrm{~min}$ of low-acid canned foods is required for their inactivation. Clostridium sporogenes is often viewed as a non-toxigenic equivalent of $C$. botulinum Group I [6]. C. botulinum Group II strains forming type B or type E neurotoxin are most frequently associated with foodborne botulism due to spore survival in the pasteurization process and their ability to germinate and produce neurotoxin at refrigeration temperatures. The minimum growth temperature for this bacterium is $3{ }^{\circ} \mathrm{C}$ [7]. The first strain of C. botulinum of this type (C. botulinum Group II, type B) was isolated by Emilie van Ermengem in 1897, following an outbreak of foodborne botulism involving salted ham in Ellezelles, Belgium [6]. Recent foodborne botulism outbreaks in Iceland, the United Kingdom, and France were also associated with C. botulinum Group II, type B [6]. C. botulinum group III strains producing neurotoxins types $C, D$, and chimers C/D and $\mathrm{D} / \mathrm{C}$ are mainly connected to animal botulism, and C. botulinum group IV is a rarer group that produces neurotoxin of type G [8].

The initial symptoms of foodborne botulism are often confused with more common health concerns such as stroke, myasthenia gravis, Eaton-Lambert syndrome, or tick paralysis [5]. The treatment includes gastrointestinal decontamination, administration of the specific antidote, and, when necessary, respiratory support. Two primary BoNT antitoxins, trivalent (A, B, and E) and heptavalent (A, B, C, D, E, F, and G), can neutralize the free circulating toxins, preventing their binding to the neuromuscular junction [5]. However, there is a growing interest in developing novel strategies to treat botulism. Recently, a new methodology using atoxic derivatives of BoNT to transport therapeutic antibodies into the neuronal cytosol to bind and neutralize BoNT has been developed [9]. Modern technology may enable the delivery of antibodies and other protein-based therapeutics to previously inaccessible intraneuronal targets [10]. Another strategy is using bacteriophage (viruses that infect bacteria) lytic enzymes, called endolysins, to treat and prevent botulism. Typically, endolysins degrade bacterial peptidoglycan at the end of the bacteriophage lytic cycle to facilitate phage progeny release. These enzymes can recognize and digest a specific chemical bond(s) within peptidoglycan and therefore can be classified as $N$-acetylmuramidases (lysozymes), $N$-acetyl- $\beta$-D-glucosaminidases (glycosylases), $N$-acetylmuramoyl-L-alanine amidases, L-alanoyl-D-glutamate endopeptidases, and interpeptide bridge-specific endopeptidases [11].

Researchers have long searched for and characterized new endolysins for extracellular use to combat bacterial infections. Until now, several phage endolysins have been shown to exhibit antibacterial activities against different Clostridium strains. The most studied examples are endolysins active against Clostridium perfringens, the third leading cause of human foodborne illnesses [12]. Ply3626 was the first discovered endolysin of $C$. perfringens bacteriophage [13], and since then, a few others, including PlyCP390 and PlyCP26F [14], Psm-his [15], PlyCM [16], CP25L [17], PlyCP10, PlyCP41 [12], LysCPS2 [18], LysCP2 [19], and LysCPAS15 [11], have been characterized. In general, lytic enzymes of $C$. perfringens phages, like many endolysins of bacteriophages of Gram-positive bacteria, have two domains: the enzymatically active domain (EAD) responsible for the catalytic function of the protein and the cell-wall-binding domain (CBD) that targets the endolysin to the host. Due to the presence of the CBD, which specifically recognizes and noncovalently binds to the ligand molecules within the bacterial cell envelope, C. perfringens phage endolysins display a narrow host spectrum limited to the bacteria of the Clostridium 
genus [11]. Recently, several putative endolysins with activity of N-acetylmuramoyl-Lalanine amidases with amidase_2 or amidase_3 catalytic domains have been identified in the genomes of bacteriophages/prophages of Clostridium difficile strains [20]. Two of them, CD27L and PlyCD, are active against several C. difficile isolates and were characterized in detail [21,22]. Single endolysins targeting Clostridium tyrobutyricum (CTP1L), Clostridium sporogenes (CS74L), and C. botulinum Group I cells (CBO1751) were also reported [23-25]. Despite extensive efforts to understand the structure-function relationship of endolysins from Clostridium bacteriophages [26,27], there is still little demonstration of their practical applications. No endolysin of bacteriophage of C. botulinum Group II has been described so far.

Recent studies in our laboratory resulted in the discovery of two thermostable endolysins, Ph2119 (GenBank accession no. AHF20915.1) and Ts2631 (AIM47292.1), with amino acid sequence similarity to eukaryotic peptidoglycan recognition proteins (PGRPs) [28-30]. Both enzymes, derived from Thermus scotoductus bacteriophages, Ph2119 and vB_Tsc2631, show strong muralytic activity against bacteria of genus Thermus. Interestingly, they were also active against mesophilic Gram-negative bacteria such as Escherichia coli, Serratia marcescens, Pseudomonas fluorescens, and Salmonella enterica serovar Panama. On the other hand, they were not active against mesophilic Gram-positive bacteria, except for Bacillus cereus [28,29]. Recently, our group demonstrated the antibacterial activity of Ts2631 endolysin against Acinetobacter baumannii and Pseudomonas aeruginosa [31]. Both bacteria are included on the World Health Organization (WHO) list of antibiotic-resistant "priority pathogens" for which new antibiotics are urgently needed [32].

Here, in search of novel antibacterial agents, we performed bioinformatics analysis to identify lytic enzymes similar to thermostable Ph2119 and Ts2631 endolysins. We identified and characterized a novel endolysin named LysB from the prophage of $C$. botulinum E3 strain Alaska E43. The predicted endolysin was overexpressed in Escherichia coli Tuner(DE3) and exhibited lytic activity against bacteria of Clostridium genus, Deinococcus radiodurans, and Staphylococcus aureus. No lysis of Gram-negative bacteria was observed. Size-exclusion chromatography and analytical ultracentrifugation showed that the protein is dimeric in solution. LysB can bind to lipoteichoic acids, a significant constituent of the Gram-positive bacterial cell wall, and in silico analysis showed that twelve residues (M13, H43, N47, G48 W49, A50, L73, A75, H76, Q78, N81, and Y182) might be involved in this interaction.

\section{Results}

\subsection{In Silico Analysis in Search of Lytic Enzymes}

BLASTP computational analysis revealed that thermostable Ph2119 and Ts2631 endolysins show homology not only to PGRP proteins and a putative lytic enzyme from Thermus thermophilus bacteriophage PhiKo (AYJ74695.1), but also to several hypothetical, annotated N-acetylmuramoyl-1-alanine amidases (EC 3.5.1.28), which are lytic enzymes of different Clostridium species (C. perfringens, C. sporogenes, C. pasteurianum, C. intestinale, and C. botulinum) (Figure 1). Among them, there was a putative lytic protein of 224 amino acids encoded in the genome of C. botulinum strain E3 Alaska E43 (GenBank CP001078.1), designated as LysB (GenBank ACD52487). 


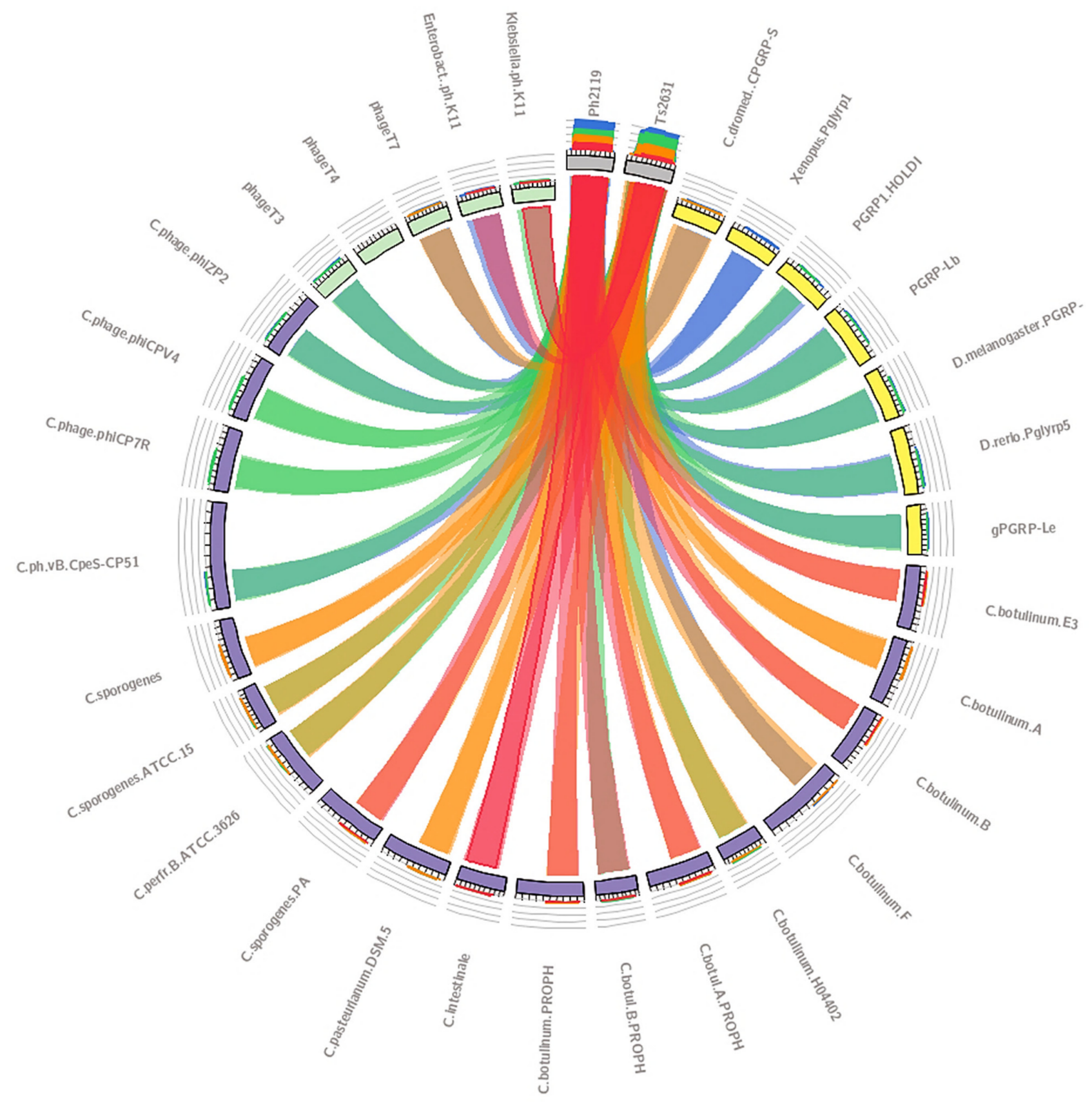

Figure 1. The similarity analysis of thermostable endolysins Ph2119 and Ts2631 compared to phage and bacterial lytic enzymes including Clostridium enzymes and eukaryotic proteins recognizing peptidoglycan (PGRPs), visualized using Circoletto software [33]. The Basic Local Alignment Search Tool (BLAST) sequence comparison results are represented in four quartiles, each shown in a different color pattern. Red ribbons reflect the highest score, corresponding to 33-34\% amino acid sequence identity, orange and green indicate medium scores, and blue indicates the lowest percentage of identity ( $26 \%$ ). The width of the ribbons represents alignment length. Original dataset with the protein amino acid sequences and their respective GenBank or Protein Data Bank (PDB) accessions numbers and the BLAST results with E values are available as Supplementary Materials S1 and S2.

We have selected this protein for further study, since the recent rise in the emergence of multidrug-resistant virulent Clostridium strains underpins the necessity of developing novel therapeutic strategies [34]. The availability of the biosafety level $1 \mathrm{C}$. sporogenes strain that is often used as a surrogate for $\mathrm{C}$. botulinum and does not produce the botulinum neurotoxins [35] also favours our selection. 
Analysis of the complete genomic sequence of the C. botulinum strain E3 Alaska E43 with the prophage prediction tool PHASTER revealed the presence of the prophage region. Despite its relatively small genome size of $47,6 \mathrm{~kb}$, the putative prophage showed the overall modular organization following bacteriophages of the Siphoviridae family. It consisted of lysogeny, DNA metabolism, DNA packing, head morphogenesis, tail morphogenesis, and host cell lysis modules [36-38]. Putative functions of open reading frames (ORFs) were assigned based on conserved domain searches (https:/ / pfam.xfam.org/) (Table S2). In the group responsible for host lysis, there were two interesting ORFs. The first ORF, 675-bp, encoded an endolysin, an $\mathrm{N}$-acetylmuramoyl-L-alanine amidase (LysB) of 224 amino acids, and the second ORF, 417-bp, encoded a holin, a protein of 138 amino acids, which triggers cell lysis (Figure 2).

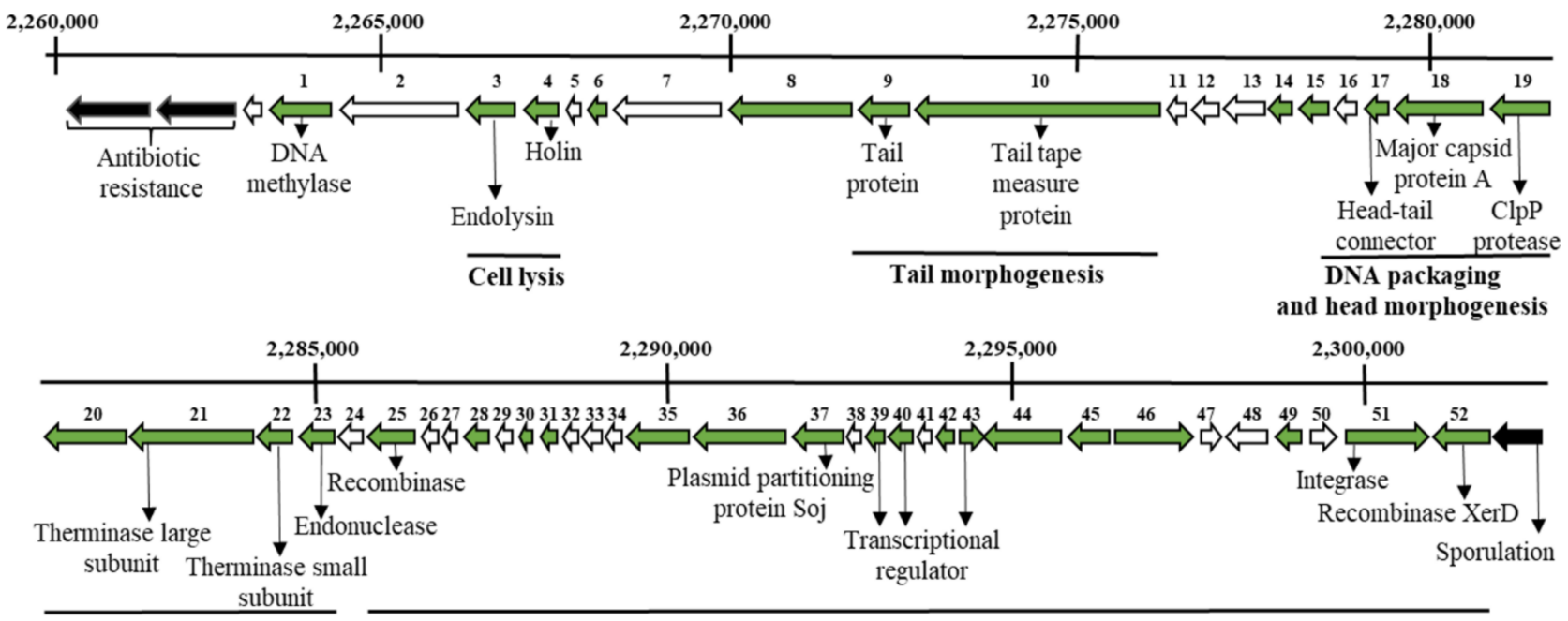

Bacterial ORF $\langle$ Hypothetical ORF $\prec$ Phage ORF

DNA metabolism and lysogeny?

Figure 2. A fragment of C. botulinum E3 strain Alaska E43 genome map with predicted open reading frames (ORFs) within the prophage region. ORFs are depicted as arrows in the expected direction of transcription. Gray: bacterial ORF, green: phage ORF, white: hypothetical ORF. Putative functions were assigned based on conserved domain searches. The scheme was performed based on a graphical view of the complete genome sequence of C. botulinum E3 strain Alaska E43 (https: / / www.ncbi.nlm.nih.gov / nuccore/CP001078.1?report=graph; Accessed on 25 May 2021).

Conserved Domain Database [39] and Pfam [40] analysis assigned to the LysB endolysin an $\mathrm{N}$-acetylmuramoyl-L-alanine amidase domain of the amidase_2 class, with a $\mathrm{Zn}^{2+}$ catalytic site (Pfam01510). In T7 lysozyme [41] and Ts2631 endolysin [29], the $\mathrm{Zn}^{2+}$ coordination site consists of two histidines and one cysteine. In T7 lysozyme, additional tyrosine is bound to $\mathrm{Zn}^{2+}$ through a water molecule [41]. Despite the fact that the amino acid sequence of LysB shows only $31.67 \%$ identity to Ts2631 endolysin (E value $7 \times 10^{-16}$ ) and $31.75 \%$ identity to $\mathrm{T} 7$ lysozyme ( $\mathrm{E}$ value $\left.=1 \times 10^{-17}\right)$, the $\mathrm{Zn}^{2+}$ catalytic triad $(\mathrm{H} 25$, $\mathrm{H} 126, \mathrm{C} 134)$ is conserved in the LysB endolysin sequence (Figure 3). In addition, the enzyme shares $31.48 \%$ sequence identity to gPGRP-LE from Drosophila melanogaster (E value $\left.=3 \times 10^{-13}\right), 32.6 \%$ to PGRP-LB from the same species $\left(E\right.$ value $\left.=5 \times 10^{-17}\right)$, and $33.7 \%$ to CPGRP-S from Camelus dromedarius (E value $=3 \times 10^{-12}$ ). PGRPs are innate immunity proteins prevalent in insects, mollusks, echinoderms, and vertebrates. They contain a conserved $C$-terminal PGRP domain that is homologous to bacteriophage and bacterial type 2 amidases. PGRPs recognize bacterial peptidoglycan and, in some cases, may hydrolyze it, leading to bacterial cell death [42]. 


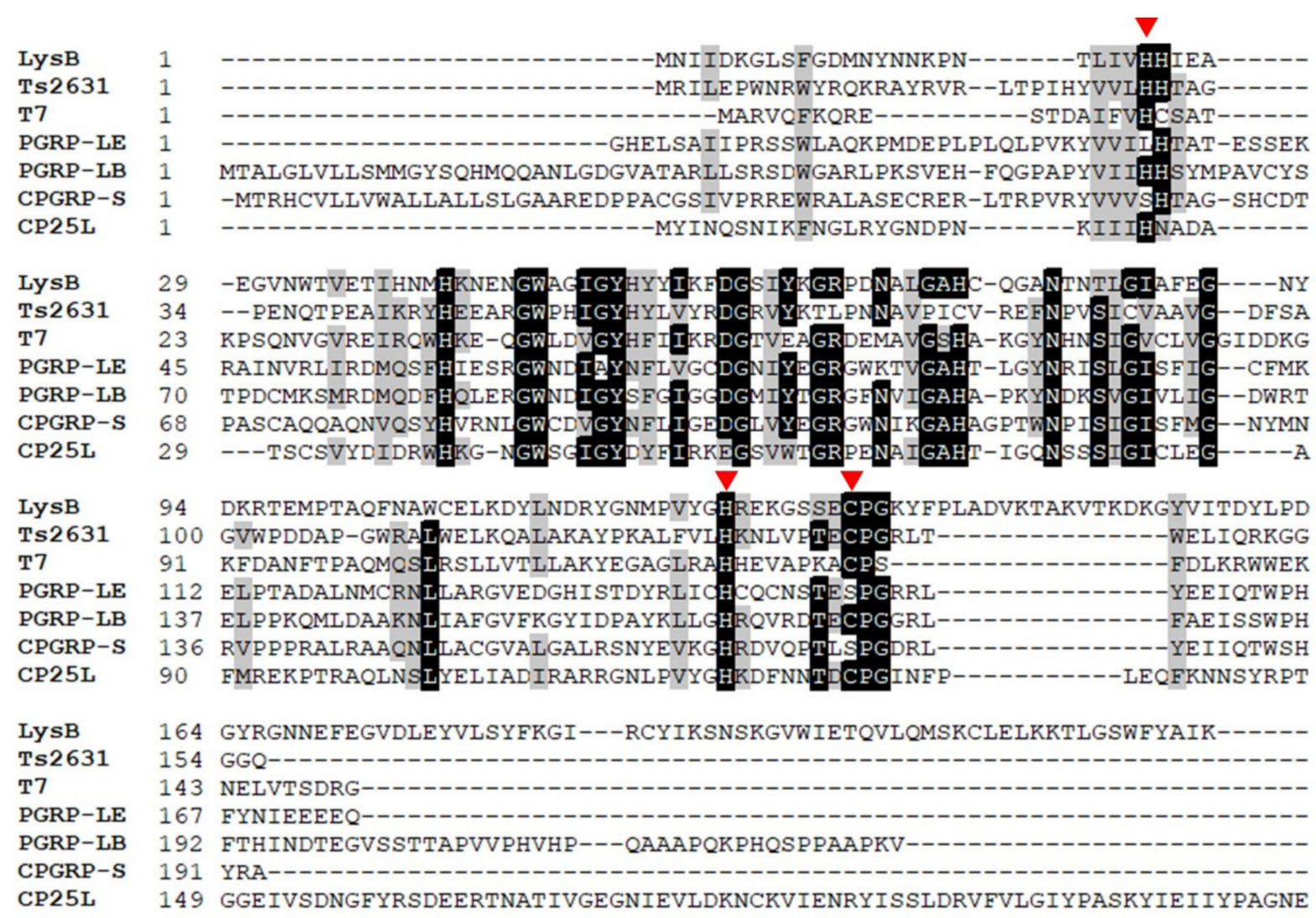

Figure 3. Multiple alignment of the amino acid sequence of LysB endolysin shows its homology to Ts2631 endolysin, T7 lysozyme, and eukaryotic peptidoglycan recognition proteins (PGRPs). GenBank or PDB accession numbers are LysB (ACD52487), Ts2631 from T. scotoductus phage vB_Tsc2631 (AIM47292.1), T7 from enterobacteria phage T7 (AAB32819.1), gPGRP-LE from D. melanogaster (PDB entry: 2CB3_B), PGRP-LB from D. melanogaster (PDB entry: 1OHT_A), CPGRP-S from C. dromedarius (PDB entry: 3O4K), CP25L from C. perfringens phage vB_CpeS-CP51 (AGH27916.1). The red triangles indicate residues responsible for $\mathrm{Zn}^{2+}$ binding $(\mathrm{H} 25, \mathrm{H} 126, \mathrm{C} 134)$. The alignment was generated with the Clustal Omega program with default options. The black background represents $100 \%$ amino acid sequence identity, while the gray background indicates amino acid conservation at $70 \%$.

\subsection{Expression and Purification of LysB Endolysin}

The gene sequence (675-bp) encoding LysB endolysin was codon-optimized for E. coli codon usage. The amplified gene was cloned into expression vector $\mathrm{pET} 15 \mathrm{~b}$ to construct a pET_LysB recombinant plasmid (with a $6 \times$ His tag for ease of purification). First trials to purify the LysB endolysin after standard overproduction at $37^{\circ} \mathrm{C}$ showed that after sonication, the protein was present only in an insoluble protein fraction (P) (Figure 4a). Therefore, it was decided to lower the temperature during the LysB endolysin overproduction, and after the induction step, incubation was carried out for $4 \mathrm{~h}$ at $30^{\circ} \mathrm{C}$ or overnight at $18{ }^{\circ} \mathrm{C}$. The overproduction of LysB at $18{ }^{\circ} \mathrm{C}$ resulted in the presence of LysB (seen in Figure $4 \mathrm{a}$ ) in the supernatant (S), in an amount sufficient to conduct further purification steps. The LysB endolysin was purified using immobilized metal affinity chromatography (IMAC) as outlined under Materials and Methods. The purification yield from $1 \mathrm{~L}$ of $E$. coli Tuner(DE3) (pET15b_LysB) culture was $37.5 \mathrm{mg}$, with a final purified protein concentration of $15 \mathrm{mg} / \mathrm{mL}$ achieved. The LysB endolysin with $N$-terminal hexahistidine tag (His-tag) had a predicted molecular weight of 27,726 and isoelectric point of 7.09 (as evaluated by the IPC tool), which corresponded well to the protein size determined by the SDS-PAGE (Figure $4 b$ ). 
(a)

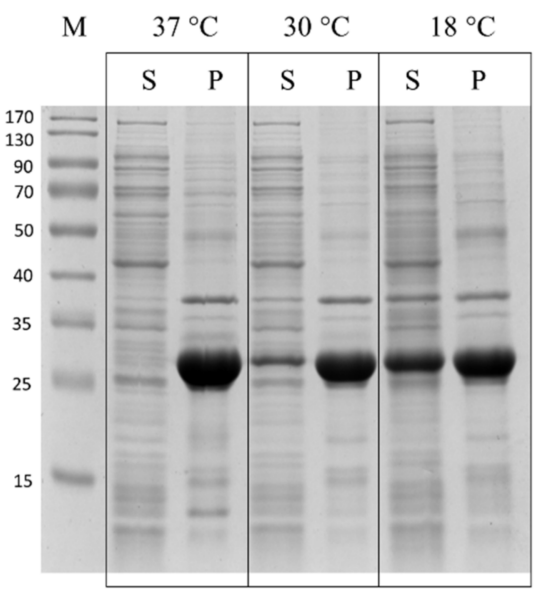

(b)

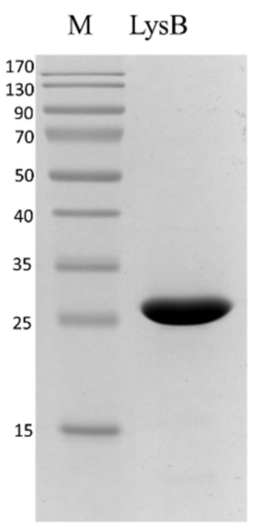

Figure 4. Overproduction and purification of LysB endolysin. (a) Overproduction in E. coli Tuner(DE3) cells was carried out with $1 \mathrm{mM}$ IPTG for $4 \mathrm{~h}$ at both $37{ }^{\circ} \mathrm{C}$ and $30{ }^{\circ} \mathrm{C}$ or overnight at $18{ }^{\circ} \mathrm{C}$. Then cells were harvested, and after sonication, cell lysates were centrifuged to obtain clear supernatant with soluble proteins (S) and pellet (P) fractions. (b) Purified LysB endolysin. All samples were mixed with Laemmli buffer and loaded on 12.5\% SDS-PAGE. Gels were stained with Coomassie Brilliant Blue R-250. (M) Protein standards where values at left indicate molecular masses (in kDa) (Thermo Fisher Scientific, Waltham, MA USA).

\subsection{Bacteriolytic Spectrum of LysB Endolysin}

The bacteriolytic activity of LysB endolysin was tested against several Gram-positive and Gram-negative bacterial strains (Figure 5a). In the zymogram assay, LysB was active against C. sporogenes ATCC 7955, Clostridium intestinale ATCC 49213, Bacillus cereus ATCC 13061, Bacillus megaterium ATCC 14581, Bacillus mycoides KPD 15, Bacillus thuringensis KPD 114, S. aureus ATCC 25923, and D. radiodurans ATCC 13939. The lysis is shown as a white band on the dark background. No lysis was observed in the case of bovine serum albumin (BSA), which served as a negative control (Figure 5b). Endolysin did not show activity against Bacillus pumilus KPD 181, Bacillus subtilis ATCC 6633, E. coli MG1655, Listeria monocytogenes KPD 1326, Micrococcus luteus ATCC 7468, Streptococcus pyogenes KPD 457, S. enterica serovar Panama KPD 101, or Thermus flavus MAT 1087 (Summary in Table S3). In addition, turbidity reduction assays of LysB endolysin against C. perfringens $\mathrm{Cp} 39$ and C. perfringens JGS1504 under conditions specified in the Materials and Methods section showed activity of the protein against $C$. perfringens $C$ p39 strain (Figure $5 \mathrm{c}$ ) and moderate activity against $C$. perfringens JGS1504 (Figure 5d).

\subsection{Optimal Conditions for LysB activity}

The enzyme lytic activity was examined under different conditions using turbidity reduction assay and C. sporogenes ATCC 7955 cells as a substrate. The LysB endolysin showed the highest activity at $\mathrm{pH} 6.0$, significantly reduced below $\mathrm{pH} 5.0$ and above $\mathrm{pH}$ 6.5 (Figure 6a). At pH 4.0 and 7.0, the activity was reduced to $4.3 \%$ and $24.9 \%$, respectively, compared to the maximal lytic activity at $\mathrm{pH}$ 6.0. The effect of ionic strength on the functionality of LysB endolysin was estimated at concentrations of $\mathrm{NaCl}$ ranging from 0 to $300 \mathrm{mM}$ (Figure 6b) and concentrations of buffer MES-NaOH, $\mathrm{pH}$ 6.0, between 10 and $100 \mathrm{mM}$ (Figure $6 \mathrm{c}$ ). The highest lytic activity was observed without salt added and when $20 \mathrm{mM}$ MES-NaOH, $\mathrm{pH}$ 6.0, was used as a reaction buffer. The presence of $10 \mathrm{mM}$ $\mathrm{NaCl}$ was sufficient to drop activity to $53.2 \%$, and the gradual increase in salt concentration resulted in a further decrease in LysB endolysin functionality (which was $5.8 \%$ at $300 \mathrm{mM}$ $\mathrm{NaCl}$, relative to the highest enzyme activity in the absence of salt). Therefore, further experiments were performed in $20 \mathrm{mM}$ MES-NaOH buffer, $\mathrm{pH}$ 6.0, with no $\mathrm{NaCl}$ added. The optimal temperature for LysB activity was $30^{\circ} \mathrm{C}$ (Figure 6d). The enzyme showed 
$79.2 \%$ of activity at $42{ }^{\circ} \mathrm{C}$, but the further increase in the assay temperature caused a drop in LysB activity to less than $15 \%\left(14.3 \%\right.$ at $\left.50{ }^{\circ} \mathrm{C}\right)$.

(a)

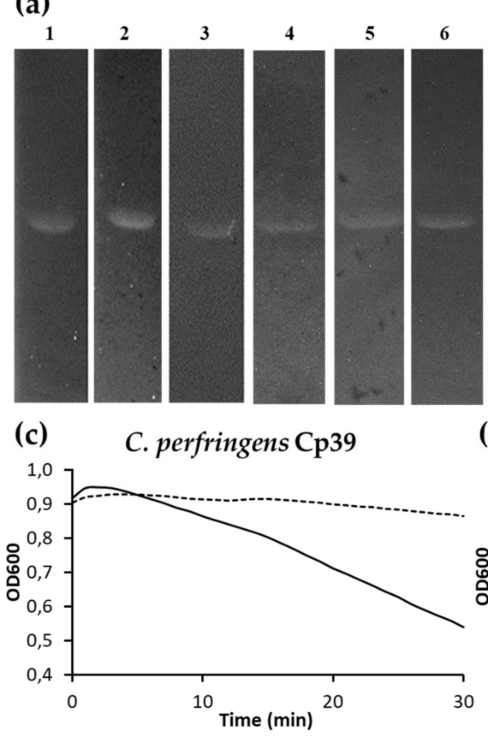

(b)

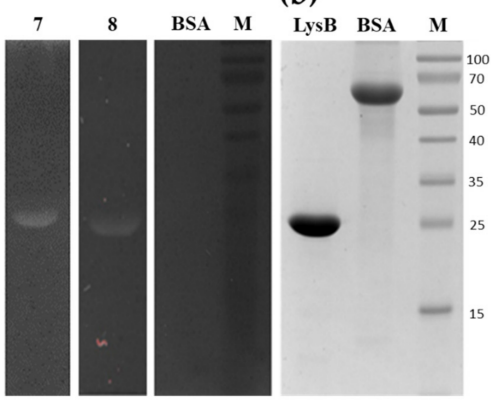

(d) perfringens JGS1504

Figure 5. Lytic activity of LysB endolysin. (a) Zymogram containing (1) C. sporogenes ATCC 7955, (2) C. intestinale ATCC 49213, (3) B. cereus ATCC 13061, (4) B. megaterium ATCC 14581, (5) B. mycoides KPD 15, (6) B. thuringensis KPD 114, (7) S. aureus ATCC 25923, (8) D. radiodurans ATCC 13939, and bovine serum albumin (BSA). (b) SDS-PAGE (12.5\%) analysis of purified LysB endolysin (LysB) and BSA as a quantity control; results of turbidity reduction assay against (c) C. perfringens Cp39 and (d) C. perfringens JGS1504. The dotted lines indicate controls (cells without endolysin), and solid lines indicate bacterial cells incubated at $22{ }^{\circ} \mathrm{C}$ with LysB at a concentration of $100 \mu \mathrm{g} / \mathrm{mL}$. The data shown represent one of three independent experiments. (M) Protein standards where values at right indicate molecular masses (in kDa) (Thermo Fisher Scientific, Waltham, MA, USA).

(a)

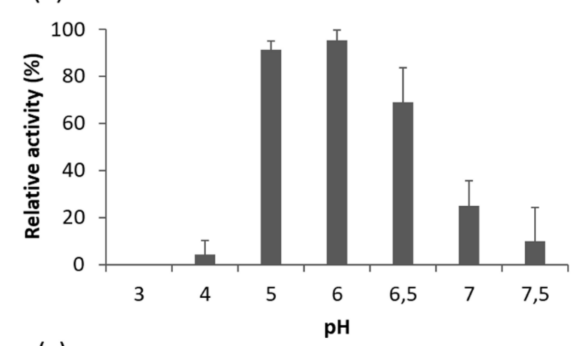

(c)

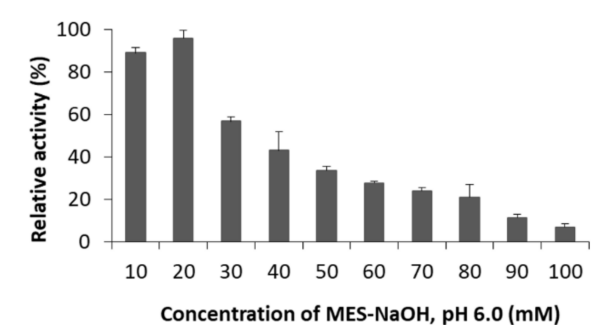

(b)

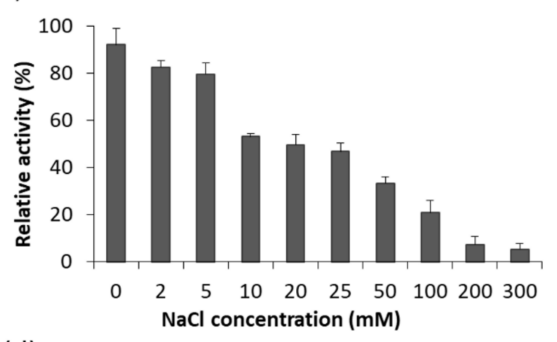

(d)

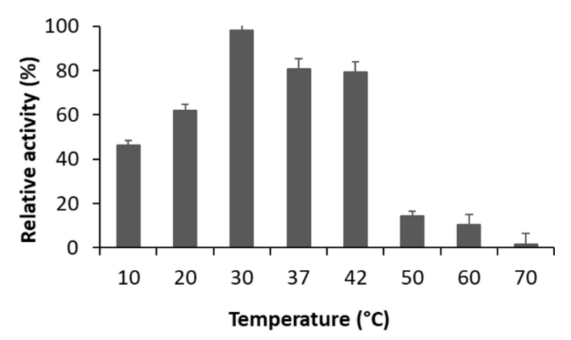

Figure 6. Effects of (a) $\mathrm{pH}$; (b) $\mathrm{NaCl}$; (c) the optimal value of the buffer concentration; and (d) temperature on the lytic activity of LysB against C. sporogenes ATCC 7955 cells. Relative activity was calculated by comparing the lytic activity at a specific condition with the maximal lytic activity within the dataset. Each experiment was repeated in triplicate, error bars indicate the standard deviations. 


\subsection{Electron Microscopy Experiments}

The effects of LysB endolysin activity on the morphology of C. sporogenes ATCC 7955 cells were visualized using transmission electron microscopy (TEM). In the control experiment, the cell shape of the untreated bacteria remained unaltered (Figure 7a). The exposure of the bacteria to LysB at a concentration of $50 \mu \mathrm{g} / \mathrm{mL}$ for 20 min caused significant changes in the shape of the cells. The bacteria exposed to LysB endolysin exhibited many abnormalities in morphology, including disruption of the cell wall, detachment of cellular membrane, an outflow of cellular content, and cellular disintegration (Figure $7 \mathrm{~b}$ ).

(a)

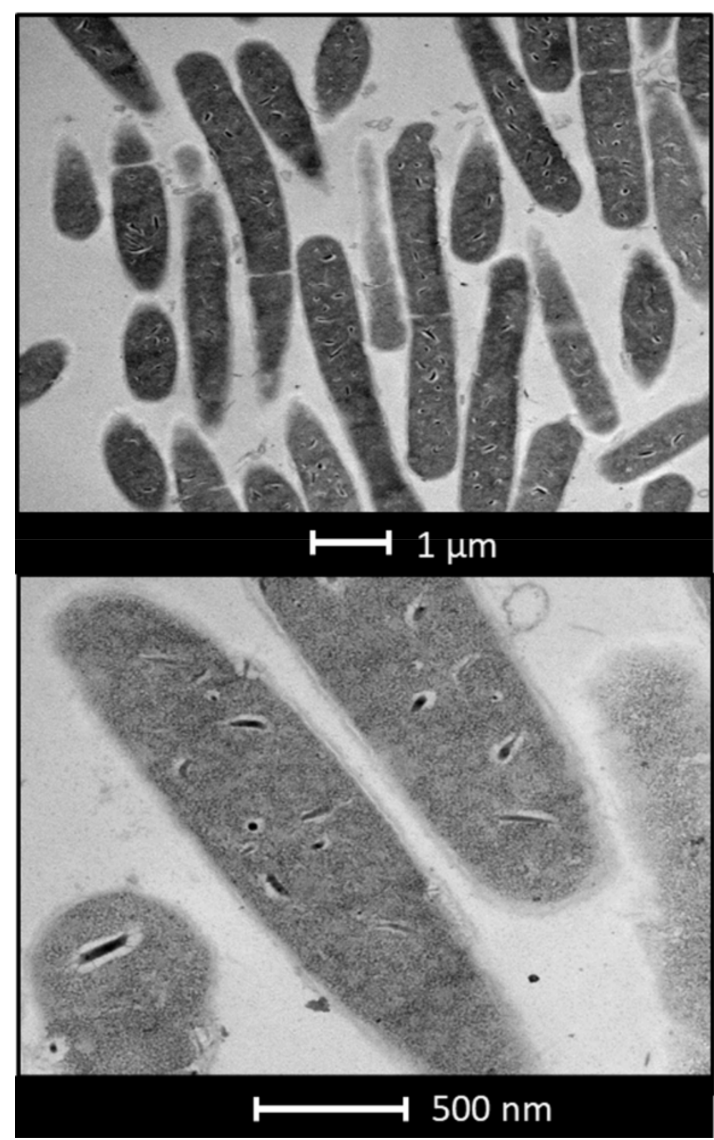

(b)

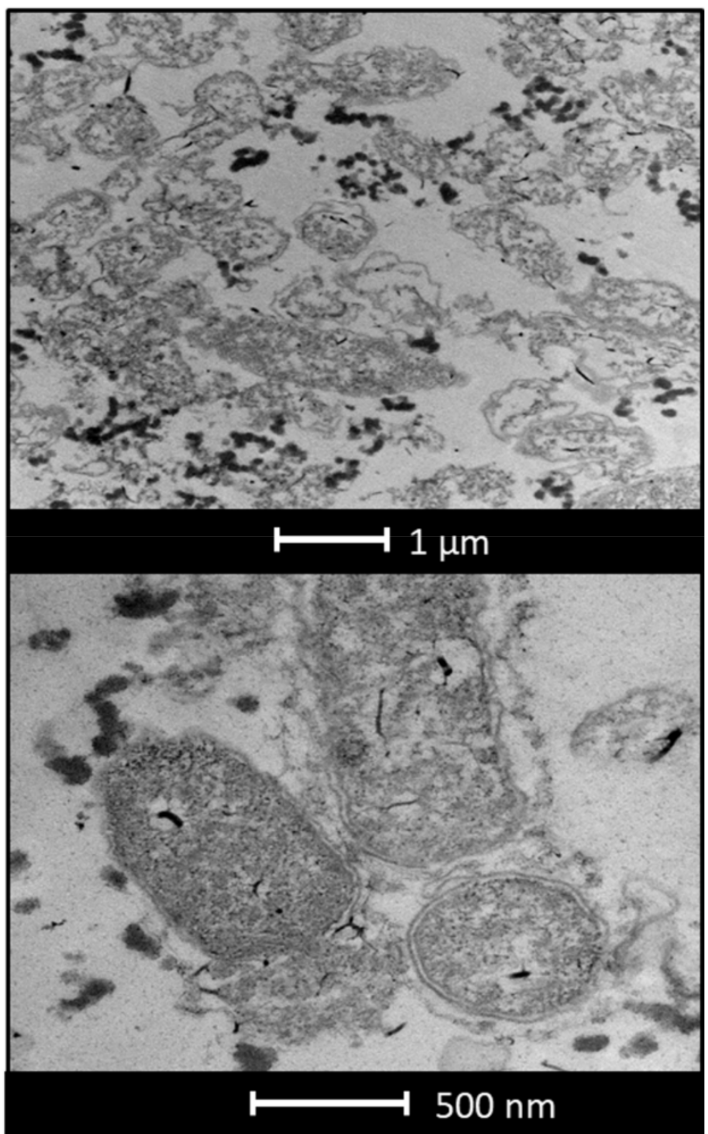

Figure 7. Transmission electron microscopy of LysB-treated C. sporogenes ATCC 7955. (a) Untreated C. sporogenes cells, (b) C. sporogenes treated with $50 \mu \mathrm{g} / \mathrm{mL}$ LysB for $20 \mathrm{~min}$.

\subsection{Oligomeric State of LysB Endolysin}

To determine the oligomeric state of LysB endolysin, the purified protein sample was subjected to size-exclusion chromatography (SEC) and analytical ultracentrifugation (AUC). The results are shown in Figure 8. As a reference, SEC of the control's dextran blue (2000 kDa), bovine serum albumin (66 kDa), trypsin inhibitor (20 kDa), cytochrome C $(12.4 \mathrm{kDa})$, and aprotinin $(6.5 \mathrm{kDa})$ was performed. The elution profile of the LysB protein revealed a single peak with an elution volume of $9.55 \mathrm{~mL}$ that corresponds to a molecular weight of 60,000 (Figure 8a). This SEC result suggests that the protein exists in a dimeric form (homodimer) in solution. The analysis also indicated high homogeneity of the protein, suggesting a lack of aggregation. The AUC experiments further supported these results, where by nonlinear fittings, average molecular weights of LysB endolysin were determined as 27,400 (monomer) and 56,900 (dimer) (Figure 8 b,c). The experimentally determined molecular weight (MW) of LysB monomer (peak 1, Figure 8c) corresponds well with the calculated MW based on the protein sequence $\left(\mathrm{M}_{r}=27,726\right)$. Moreover, the results of both 
size-exclusion chromatography and analytical ultracentrifugation agree that in solution, LysB endolysin exists predominantly as a homodimer.

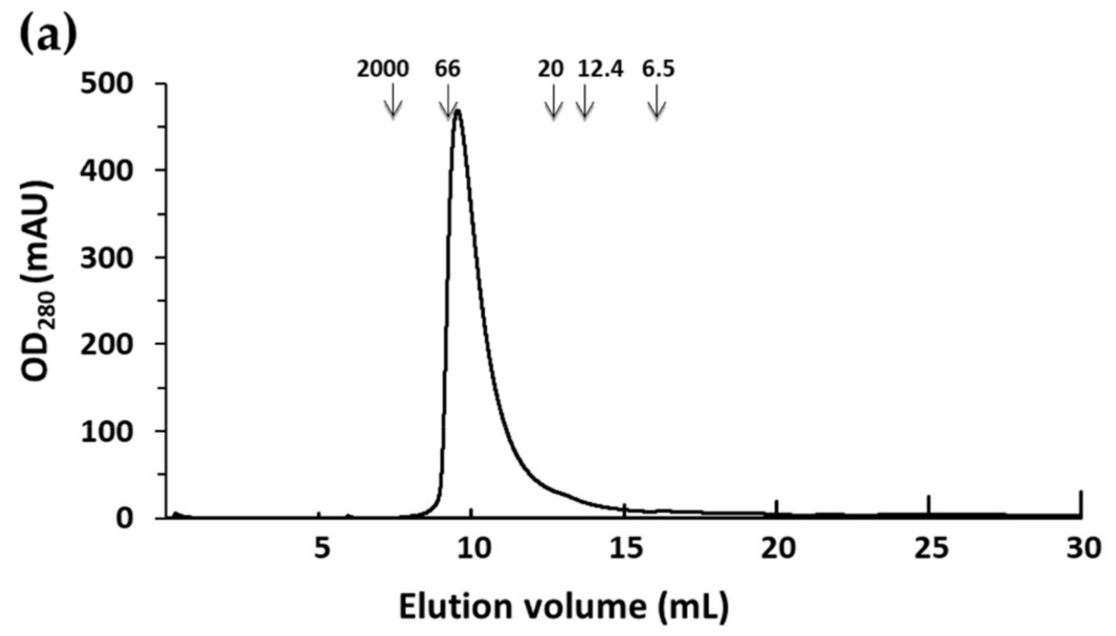

(b)

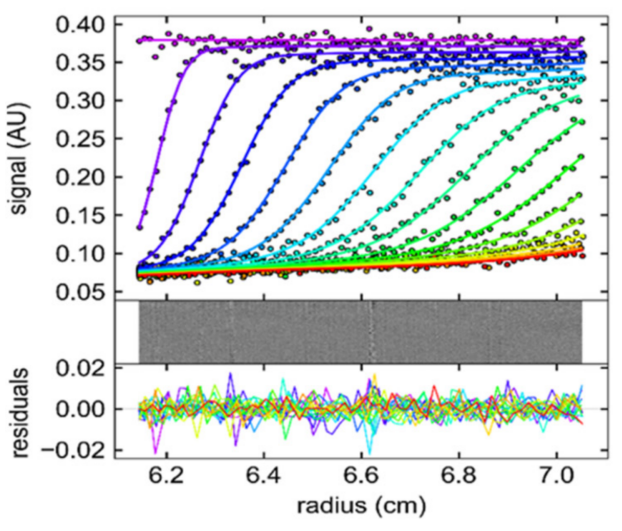

(c)

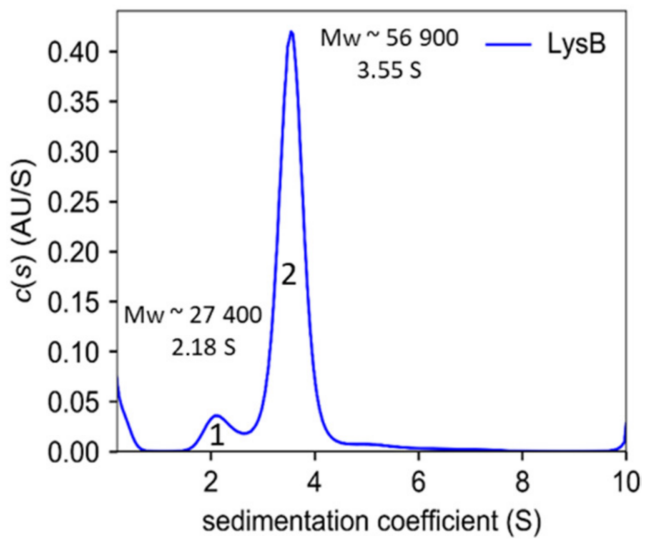

Figure 8. Size-exclusion chromatography and sedimentation velocity analytical ultracentrifugation analysis of LysB. (a) Elution profile of LysB endolysin on Superdex 75 sizing column. LysB endolysin $(3 \mathrm{mg} / \mathrm{mL})$ in a final volume of $300 \mu \mathrm{L}$ was loaded on Superdex 75 10/300 GL (AKTA Pure chromatography system, GE Healthcare, Little Chalfont, UK) and eluted at a flow rate of $0.8 \mathrm{~mL} / \mathrm{min}$ in buffer consisting of $25 \mathrm{mM} \mathrm{NaH}_{2} \mathrm{PO}_{4}, 150 \mathrm{mM} \mathrm{NaCl}, \mathrm{pH}$ 8.0. Elution of LysB endolysin was detected by absorption at $280 \mathrm{~nm}$ (mAU, milli-absorbance units). The position of molecular mass standards are shown as arrows: dextran blue: $2000 \mathrm{kDa}$, bovine serum albumin: $66 \mathrm{kDa}$, trypsin inhibitor: $20 \mathrm{kDa}$, cytochrome C: $12.4 \mathrm{kDa}$, aprotinin: $6.5 \mathrm{kDa}$. (b) Sedimentation velocity data were overlaid with the best-fit curves (lines) obtained from sedimentation coefficient distribution analysis. For the clarity of the drawing, only every fifth scan and fifth data point are shown. Below, residuals of the experimental fits. (c) Sedimentation coefficient distributions (c(s)) of LysB endolysin. Peak 1 corresponds to LysB monomer; peak 2 corresponds to LysB homodimer.

\subsection{Interaction between LysB and Lipoteichoic Acid}

Eukaryotic PGRPs and bacteriophage endolysins, apart from binding to peptidoglycan, may interact with other components of bacterial cell wall such as wall teichoic acids (WTAs) and membrane-anchored lipoteichoic acids (LTAs) [43,44]. The CBD of Listeria bacteriophage endolysin PlyP35 interacts with $N$-acetylglucosamine residues in WTAs [44], while the camel PGRP-S (CPGRP-S) binds to S. aureus LTAs [43]. In silico comparative analysis showed that LysB endolysin has conserved residues responsible for LTAs binding. A molecular model of the LysB endolysin based on the short form of camel PGRP (CPGRP-S) structure (PDB entry: 3O4K) illustrates LTA binding sites (M13, H43, N47, G48 W49, A50, L73, A75, H76, Q78, N81, and Y182); for more details, see Figure 9a. A 
representative binding isotherm for S. aureus LTA-LysB interactions in $20 \mathrm{mM}$ potassium phosphate buffer, $\mathrm{pH} 8.0,10 \%$ glycerol at $25^{\circ} \mathrm{C}$, is shown in Figure $9 \mathrm{~b}$. The thermodynamic parameters, namely binding constant $\left(\log K_{\mathrm{ITC}}=6.15 \pm 0.02 \mathrm{M}^{-1}\right)$ and the enthalpy change $\left(\Delta H_{\text {ITC }}=-0.77 \pm 0.02 \mathrm{kcal} \mathrm{mol}^{-1}\right)$, were obtained directly from ITC measurements by fitting isotherms (using nonlinear least-squares procedures) to a model that assumes one set of binding sites. The assumed model yields the best fit of calculated vs. experimental data. The standard thermodynamic relationships were as follows: $\Delta G_{\text {ITC }}=-R T \ln K_{\text {ITC }}=\Delta H_{\text {ITC }}-$ $\mathrm{T} \Delta S_{\text {ITC }}$ was used to calculate the free energy of binding $\left(\Delta G_{\text {ITC }}=-8.41 \pm 0.02 \mathrm{kcal} \mathrm{mol}^{-1}\right)$ and the entropy change, $\left(\mathrm{T} \Delta S_{\text {ITC }}=7.64 \pm 0.03 \mathrm{kcal} \mathrm{mol}^{-1}\right)$.

(a)

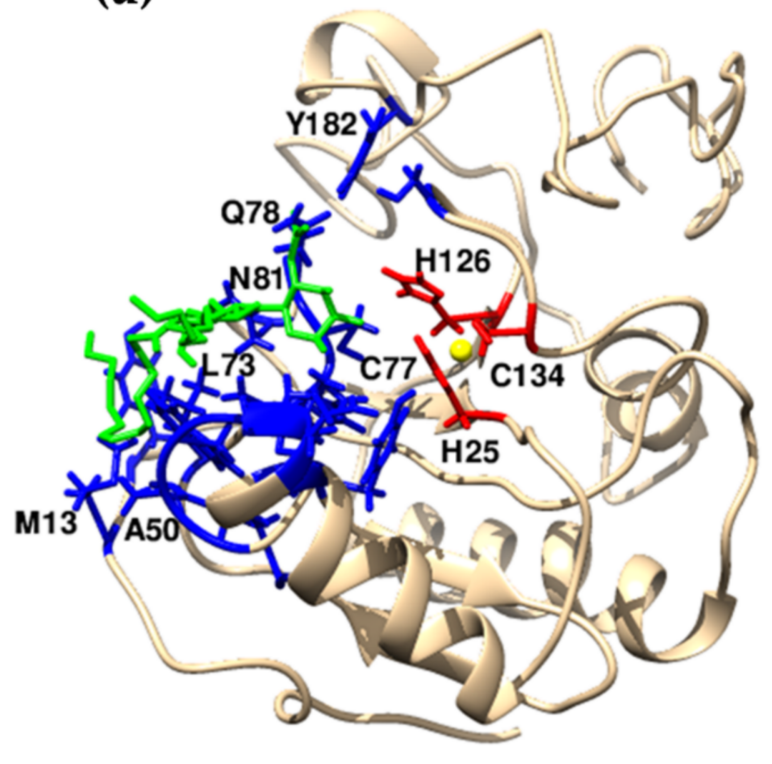

(b)

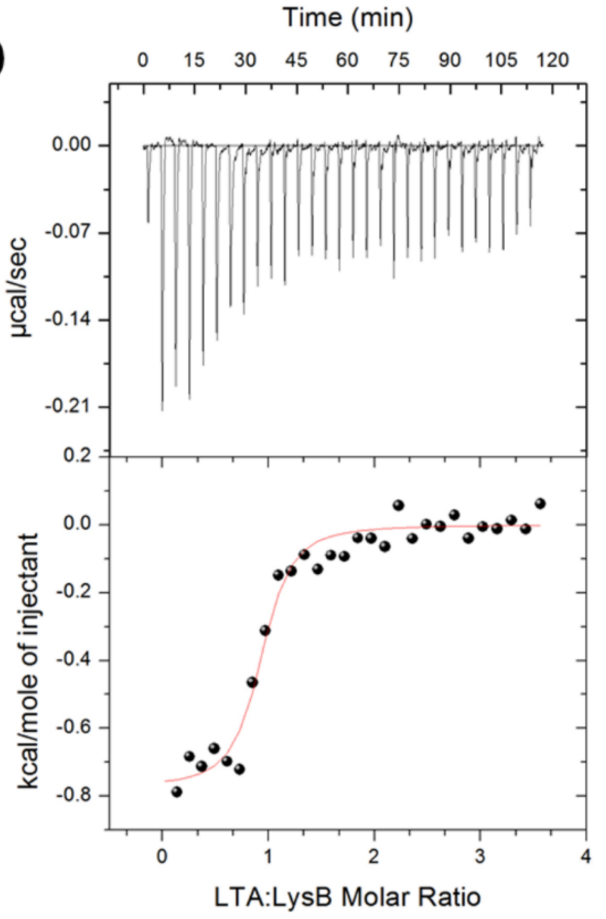

Figure 9. Interaction between LysB and lipoteichoic acid. (a) Structural model of LysB endolysin (template: PDB 3O4K). The residues M13, H43, N47, G48 W49, A50, L73, A75, H76, Q78, N81, and Y182 form the LTA binding site (3.5 Å blue zone from green LTA). H25, H126, and C 134 (red) bind $\mathrm{Zn}^{2+}$ ion (yellow). For the clarity of the presentation, only one molecule from the LysB homodimer is shown. (b) Calorimetric titration isotherm of the binding interaction between LTA and LysB in $20 \mathrm{mM}$ potassium phosphate buffer, $\mathrm{pH} 8.0,10 \%$ glycerol at $25^{\circ} \mathrm{C}$.

It is noteworthy that according to the bioinformatics analysis, the LysB catalytic domain appears to have a dual function, able to both degrade peptidoglycan and dock the protein to the bacterial cell wall. These two functions of LysB seem to be independent, as suggested by the fact that the residues involved in $\mathrm{Zn}^{2+}$ coordination and catalysis (H25, H126, and C134) are not engaged in the LTA binding (M13, H43, N47, G48 W49, A50, L73, A75, H76, Q78, N81, and Y182) (Figure 9).

\subsection{Functional Analysis of the LysB Catalytic Site}

Multiple sequence alignment of LysB endolysin and related proteins (Ts2631 endolysin from T. scotoductus bacteriophage vB_Tsc2631, T7 lysozyme, PGRP-LE and PGRP-LB from D. melanogaster, and CPGRP-S from C. dromedarius) revealed conserved residues potentially involved in $\mathrm{Zn}^{2+}$ and substrate binding (Figure 3). Previous detailed T7 lysozyme activity studies showed that tyrosine $\mathrm{Y} 46$, and lysine K128 residues play a significant role in catalysis [41]. In the amidase-active PGRPs such as PGRP-LB, threonine residue T158, which corresponds to K128 in T7 lysozyme, is highly conserved [45]. In the cases of PGRPLB and T7 lysozyme, substitutions T158K and K128T, respectively, resulted in a significant decrease in these enzymes' lytic activity [41,45]. In the LysB endolysin primary sequence, 
the Y54 residue corresponds to Y46 of T7 lysozyme, and S132 corresponds to K128 of T7 lysozyme and T158 of PGRP-LB. Moreover, three conserved residues (histidines H17 and $\mathrm{H} 122$ and cysteine, $\mathrm{C} 130$ ) that form the T7 lysozyme $\mathrm{Zn}^{2+}$ binding site correspond to residues H25, H126, and C134 in the LysB enzyme (Figure 4). All three residues are in close proximity to one another in the enzyme tertiary structure (Figure 9a). To investigate the role of $\mathrm{Zn}^{2+}$ in the lytic activity of LysB, the enzyme was treated with $5 \mathrm{mM}$ EDTA for $30 \mathrm{~min}$ at $30^{\circ} \mathrm{C}$. This treatment abolished the activity of the enzyme (Table 1). After overnight dialysis of the EDTA-treated sample against $20 \mathrm{mM}$ MES-NaOH, $\mathrm{pH}$ 6.0, $\mathrm{Zn}^{2+}$ cations were added to the protein to achieve a final concentration of 0.1 or $1 \mathrm{mM}$. The negative control for each sample contained a reaction buffer supplemented with $0.1 \mathrm{mM}$ or $1 \mathrm{mM}$ metal ions. Adding $0.1 \mathrm{mM} \mathrm{Zn}^{2+}$ reconstituted the LysB activity to $42.4 \%$, while $\mathrm{Zn}^{2+}$ at the $1 \mathrm{mM}$ concentration had no positive effect on the reaction (Table 1).

Table 1. Relative lytic activity of LysB variants. The activity was measured using turbidity reduction assay and C. sporogenes ATCC 7955 cells as a substrate. ${ }^{a}$ Lytic activity of EDTA-treated LysB. ${ }^{b}$ Lytic activity of EDTA-treated and -dialyzed LysB against chloroform-treated C. sporogenes ATCC 7955 cells supplemented with $\mathrm{Zn}^{2+}$ metal ions at $0.1 \mathrm{mM}$ concentration. ${ }^{\mathrm{c}}$ The reaction conditions were the same as in sample ${ }^{b}$, but $\mathrm{Zn}^{2+}$ was supplemented to $1 \mathrm{mM}$ concentration. $\mathrm{Nd}$ - the activity of variant $\mathrm{H} 25 \mathrm{~N}$ was not determined because it remained insoluble during purification.

\begin{tabular}{cc}
\hline Variants & Relative Activity (\%) \\
\hline LysB & $100.0 \pm 4.4$ \\
LysB + 5 mM EDTA ${ }^{\text {a }}$ & 0.0 \\
LysB + 0.1 mM Zn ${ }^{2+b}$ & $42.4 \pm 1.8$ \\
LysB + $1 \mathrm{mM} \mathrm{Zn}{ }^{2+c}$ & 0.0 \\
H25N & $\mathrm{Nd}$ \\
Y54F & $42.0 \pm 4.4$ \\
H126N & $37.0 \pm 2.9$ \\
S132K & 0.0 \\
C134S & $55.0 \pm 9.4$ \\
\hline
\end{tabular}

The involvement of conserved residues in forming the enzyme's catalytic site was tested using five amino acid substitution variants, namely H25N, Y54F, H126N, S132K, and C134S. They were purified and assayed for lytic activity against $C$. sporogenes ATCC 7955. The lytic activity of the $\mathrm{H} 25 \mathrm{~N}$ variant was not determined due to protein aggregation. In the cases of other variants, their activity was significantly lower compared to the wild-type protein: Y54F (42\%), H126N (37\%), S132K (no activity), and C134S (55\%) (Table 1). The results obtained indicate the critical role of conserved residues on the lytic activity of LysB endolysin and the requirement of $\mathrm{Zn}^{2+}$.

\section{Discussion}

This work presents the cloning, production, and characterization of the LysB lytic enzyme from a putative prophage of $C$. botulinum E3 strain Alaska E43. The location of the $l y s B$ gene in a prophage region and the presence of a holin gene adjacent to the lys $B$ gene (Figure 2, Table S2, positions 6, 7) indicate that the LysB protein is a prophage endolysin and belongs to the second class of murein hydrolases, which are transported through bacterial membranes via holes formed by holins [46]. This is in agreement with the results of the analysis performed by the PrediSi (Prediction of Signal peptides) tool, showing that the LysB enzyme lacks the signal peptide sequence responsible for protein secretion. Comparative analysis showed that LysB endolysin is $\mathrm{N}$-acetylmuramoyl-L-alanine amidase (amidase_2 domain) with $\mathrm{Zn}^{2+}$ coordination site (Pfam01510). Here, we experimentally confirmed the dependence of LysB lytic activity on the presence of zinc ions (Table 1). Amidase_2 domain with $\mathrm{Zn}^{2+}$ in the catalytic center is also present at the $\mathrm{N}$-terminal part of CP25L endolysin of C. perfringens phage vB_CpeS-CP51 [17], three predicted endolysins from podoviruses of $C$. perfringens, $\Phi C P V 4, \Phi Z P 2$, and $\Phi C P 7 R$ [47], and a putative lytic 
enzyme named CDG from Peptoclostridium difficile DA00211 strain [48]. Further analysis showed low LysB amino acid sequence identity (31.67\%) to the primary sequence of Thermus scotoductus phage Ts2631 endolysin (GenBank accession no. AIM47292.1), 31.75\% to T7 lysozyme (AAB32819.1), 32.56\% to PGRP-LB (NP_731575.1), and 39\% (amino acids 1-172) to $\mathrm{CP} 25 \mathrm{~L}$ endolysin from $C$. perfringens phage $\mathrm{vB}$ _CPeS-CP51 with $\mathrm{E}$ value $=4 \times 10^{-37}$ (AGH27916.1). No significant similarity was found between the primary sequence of LysB endolysin and CBO1751 putative amidase from the prophage of $C$. botulinum Group I strain ATCC 3502, which is the only endolysin previously characterized of $C$. botulinum background. The CBO1751 endolysin has an N-terminal amidase_3 domain (Pfam01520), with a catalytic site formed by two histidines and two glutamic acids. Bioinformatics analysis revealed that the LysB endolysin active site consists of two histidines: tyrosine and cysteine (Figure 3). The lack of primary sequence similarity between these two endolysins and significant differences in catalytic site organization indicate that LysB is a novel type of endolysin. Its characterization significantly expands knowledge of the endolysins of Clostridium botulinum bacteriophages. In contrast to the CBO1751 endolysin, which prefers alkaline $\mathrm{pH}$ (from 8.5 to 10.5) for lytic activity, LysB works at $\mathrm{pH}$ from 4.0 to 7.5 , showing the highest activity at pH 6.0 in 20 mM MES-NaOH. However, this coincides with the minimal growth $\mathrm{pH}$ ( $\mathrm{pH}$ 5.0) of C. botulinum group II (botulinum neurotoxin type E) [49], from which the tested endolysin is derived. Furthermore, the $\mathrm{pH}$ range for the activity of the LysB endolysin is similar to the CD27L endolysin of $C$. difficile bacteriophage, with amidase_3 domain, which has defined optimal pH range between 4.5 and 8.3 [22]. The optimal $\mathrm{pH}$ for activity of LysB endolysin is also similar to other Clostridium-targeting endolysins, such as PlyCP10 and PlyCP41, that have maximum activity at $\mathrm{pH} 6.0$ and $\mathrm{pH}$ 6.5, respectively [50]. The addition of $10 \mathrm{mM} \mathrm{NaCl}$ caused a decrease in the LysB endolysin functionality to $53.2 \%$, while negligible cell lysis (5.8\%) was shown at $300 \mathrm{mM}$ $\mathrm{NaCl}$. Previous studies about chimeric PlyGVE2CpCWB endolysin showed that $150 \mathrm{mM}$ $\mathrm{NaCl}$ caused a decrease in its activity to 37\% [51]; on the other hand, Clostridium perfringens phage CPS2 endolysin was highly stable in a wide range of $\mathrm{NaCl}$ concentrations [18]. Therefore, there is no specific pattern of dependence between $\mathrm{NaCl}$ concentration and lytic activity of bacteriophage endolysins of the genus Clostridium. The optimal temperature for LysB lytic activity is $30^{\circ} \mathrm{C}$, which agrees with the psychrotrophilic nature of C. botulinum Group II, which has an optimum growth temperature of $30^{\circ} \mathrm{C}$ [6].

Lytic enzymes are diverse in respect to substrate specificity. CD11 and CDG amidases of Peptoclostridium difficile are highly active against $C$. difficile clinical isolates while ineffective against Bacillus or Staphylococcal species [48]. Substrate specificity of PlyCP39O and PlyCP26F endolysins from clostridial phages phiCP39O and phiCP26F, respectively, is very narrow and includes only C. perfringens strains, as these enzymes did not lyse non-perfringens clostridial isolates. Some enzymes are active against few species, such as PlyCM, which is active against C. perfringens, C. tetani, C. septicum, and C. beijerinckii [16]; or Psm-his endolysin, which lyses C. perfringens and moderately lyses C. tetani and C. acetobutylicum [15]. In general, the LysB endolysin acts against three species of Clostridium (C. intestinale, C. perfringens, and C. sporogenes) and other Gram-positive bacteria: B. cereus, S. aureus, and D. radiodurans (in zymogram analysis, Figure 5). In this matter, LysB is similar to the CP25L endolysin of $C$. perfringens bacteriophage, which shows activity against several strains of $C$. perfringens, but also against other Gram-positive bacteria such as $B$. cereus and B. subtilis [17]. We may speculate that the similarity of catalytic domains of LysB and CP25L enzymes may determine their slightly broader substrate specificity. It could be that they both have binding domains that recognize targets that are more common among Gram-positive bacteria. Endolysins from phages of Clostridium, including LysB endolysin, show no activity against Gram-negative bacteria. That may be explained by the presence of the outer membrane as part of Gram-negative bacteria's cell wall, which is an effective barrier shielding the peptidoglycan layer against the exogenous activity of endolysins [52]. 
Residues H25, Y54, H126, and C134 of LysB endolysin correspond to residues H17, Y46, H122, and C130 of T7 lysozyme, which is a well-known type $2 \mathrm{~N}$-acetylmuramoylL-alanine amidase and can inhibit T7 RNA polymerase. Substitutions of H17 eliminated the amidase activity of T7 lysozyme [41]. Three H17 substitution variants also showed a decreased ability to inhibit T7 RNA polymerase, suggesting that these changes affected the structure of T7 lysozyme more generally [41]. Although not definitive, this is in agreement with our results, as the substitution variant of $\mathrm{H} 25$ residue, which corresponds to $\mathrm{H} 17$ of T7 lysozyme, was insoluble during purification trials, suggesting problems with protein conformation. All other LysB substitution variants, including Y54F, H126N, and C134S, revealed decreased activity, further suggesting the involvement of these residues in LysB endolysin lytic activity.

Many globular endolysins are present as monomers in the solution. This property was observed in the case of the thermostable Ts2631 endolysin, T7 lysozyme, and the catalytic domain of CD27L of $C$. difficile $\Phi C D 27$ phage [26,42,53]. However, the full-length CD27L endolysin with both catalytic and cell wall binding domains forms a dimer in solution similarly to analytical ultracentrifugation results obtained for LysB (Figure 5). The same mechanism of oligomerization as in the case of CD27L applies to the CTP1L endolysin that targets C. tyrobutyricum and the CS74L endolysin that targets C. sporogenes. There, the dimer is formed between the full-length protein and the $N$-terminally truncated $C$ terminal cell wall binding domain (CBD) [27]. The LysB endolysin does not have a known $\mathrm{CBD}$ but may contain a novel CBD that could contribute to dimer formation. A dimeric homology-based model of LysB has been proposed (Supplementary Movie S1), but further studies will be needed to confirm the mechanism of dimerization, which crystallographic studies might facilitate. Crystallography can also prove helpful for detailed analysis of the docking of the LysB endolysin to lipoteichoic acid as predicted bioinformatically. These studies were performed in the case of CPGRP-S from C. dromedarius, where the LTA was held inside the complex of four protein molecules [43]. Experimental evidence related to endolysin-LTA interactions is extremely scarce. More is known about LTAs and bacterial autolytic systems. Bacteria produce autolysins that, similarly to endolysins, hydrolyze bonds in peptidoglycan for several important bacterial physiological processes, such as cell division, cell separation, and peptidoglycan maturation. The pneumococcal cell wall autolysin LytC lysozyme specifically targets choline residues present in lipoteichoic acids of Streptococcus pneumoniae [54]. Moreover, the LTAs specifically inhibit the activity of another pneumococcal autolytic enzyme, an N-acetylmuramyl-L-alanine amidase of S. pneumoniae R36A strain, but the mechanism of this inhibition is unknown [55]. Therefore, the LysB catalytic domain's interaction with LTAs is unique and not previously encountered in the field of endolysins.

LysB endolysin is the first characterized enzyme from the prophage of $C$. botulinum group II (botulinum neurotoxin type E), lyses clostridia, and other Gram-positive bacteria such as B. cereus or S. aureus; it is an interesting enzyme for further studies to elicit its full antibacterial potential. It is especially noteworthy that phage endolysins are highly refractory to resistance development, and despite repeated attempts, no strains of host bacteria that can resist the lytic activities of their bacteriophage endolysins have been reported $[56,57]$.

\section{Materials and Methods}

\subsection{Bacterial Strains and Growth Conditions}

Clostridium sporogenes ATCC 7955, Clostridium intestinale ATCC 49213, Bacillus cereus ATCC 13061, Bacillus megaterium ATCC 14581, Bacillus subtilis ATCC 6633, Deinococcus radiodurans ATCC 13939, Micrococcus luteus ATCC 7468, and Staphylococcus aureus ATCC 25923 were purchased from the American Type Culture Collection. Thermus flavus MAT1087 was kindly provided by MATIS collection of microorganisms, Reykjavík, Iceland. Bacillus mycoides KPD 15, Bacillus thuringiensis KPD 114, Escherichia coli MG1655, Salmonella enterica serovar Panama KPD 101, Listeria monocytogenes KPD 1326, and Streptococcus pyogenes KPD 
457 came from the KPD, Collection of Plasmids and Microorganisms at the University of Gdańsk, Poland (WDCM 1084). Clostridium perfringens Cp39 cells (poultry isolate) and C. perfringens JGS1504 (swine isolate) were kindly provided by Steven M. Swift (USDA ARS NEA BARC Animal Biosciences and Biotechnology Laboratory, Beltsville, MD, USA). C. perfringens strains were grown anaerobically at $37^{\circ} \mathrm{C}$ in BYC medium $(37 \mathrm{~g} / \mathrm{L}$ brain heart infusion, $5 \mathrm{~g} / \mathrm{L}$ yeast extract, $0.5 \mathrm{~g} / \mathrm{L} \mathrm{L}-$-Cysteine). C. sporogenes ATCC 7955 and C. intestinale ATCC 49213 were cultivated under anaerobic conditions, and S. aureus ATCC 25923 under aerobic conditions at $37^{\circ} \mathrm{C}$ in tryptic soy bullion (TSB) (Graso Biotech, Starogard Gdanski, Poland). T. flavus was cultivated at $60^{\circ} \mathrm{C}$ in TM medium [28]. L. monocytogenes KPD 1326 and S. pyogenes KPD 457 were grown at $37^{\circ} \mathrm{C}$ in Brain Heart Infusion (BHI) (Graso Biotech). All other bacteria were cultivated at $37^{\circ} \mathrm{C}$ in Luria-Bertani (LB) broth [58]. When necessary, LB was supplemented with $100 \mu \mathrm{g} / \mathrm{mL}$ of ampicillin. E. coli DH5 $\alpha$ cells (Thermo Fisher Scientific, Waltham, MA USA were used for molecular cloning and site-directed mutagenesis. E. coli Tuner(DE3) cells (Sigma-Aldrich, St. Louis, MO, USA) were used for protein expression. Vector pET15b (Novagen) was used for cloning and overexpression of the gene coding for LysB endolysin.

\subsection{Computational Analysis and Molecular Modelling}

PHAge Search Tool Enhanced Release (PHASTER) [59] was used to predict the presence of a prophage region in the genome of $C$. botulinum E3 strain Alaska E43 (accessible through University of Alberta; http:/ / www.phaster.ca/; accessed on 25 May 2021). The similarity of Ph2119 and Ts2631 enzymes to phage endolysins and peptidoglycan recognition proteins was visualized with Circoletto software [33], available through the Bioinformatics Analysis Team server (http:/ / tools.bat.infspire.org; accessed on 25 May 2021). Protein sequences were aligned using the CLUSTAL Omega program with default options [60], available through the European Bioinformatics Institute website (http:/ / www.ebi.ac.uk; accessed on 25 May 2021). The molecular weight and isoelectric point of the LysB endolysin were predicted using the IPC tool [61]. The three-dimensional structure of LysB endolysin was predicted using homology modeling. A homology model was built using multiple templates (6fhg_A, 6fhg 2xz4_A, 1yb0_B, 4z8i_A, and 1lba_A) with the I-Tasser program [62], and then side chains were refined by DeepRefiner [63]. Dimerization and LTA binding were inferred using the crystal structure of peptidoglycan recognition protein (CPGRP-S) from Camelus dromedarius as the main template (PDB entry: $3 \mathrm{O} 4 \mathrm{~K}$ ) and $\mathrm{Zn}^{2+}$ located according to B. subtilis endolysin (PDB entry: 3HMB). The model was refined using USCF Chimera [64]. The files related to the bioinformatics analysis are available at: https:/ / doi.org/10.18150/NMEJQ6; accessed on 2 August 2021.

\subsection{DNA Manipulations}

Standard procedures were used for molecular cloning [58]. The synthetic lysB gene encoding the LysB putative $N$-acetylmuramoyl-L-alanine amidase (GenBank: ACD52487.1) from C. botulinum E3 strain Alaska E43 (GenBank: CP001078.1) was purchased from GeneArt Gene Synthesis Service (Life Technologies, Regensburg, Germany) with codons optimized for expression in E. coli. The gene was amplified by polymerase chain reaction (PCR) using PrimeSTAR GXL DNA polymerase (Takara Bio Europe AB, Goteborg, Sweden) and LysB_F and LysB_R primers containing NdeI and BamHI restriction sites, respectively (shaded in Table S1). The PCR product was digested with NdeI and BamHI and ligated into vector $\mathrm{pET15b}$, which has the $N$-terminal hexahistidine (His-tag) sequence. Obtained clones were verified by automated DNA sequencing. Plasmid pET15b_LysB was transformed into E. coli Tuner (DE3) for recombinant protein expression. Restriction endonucleases and DNA-modifying enzymes were purchased from Thermo Fisher Scientific Inc. Site-directed mutagenesis was utilized to introduce missense mutations in codons of five amino acids, namely His25, Tyr54, His126, Ser132, and Cys134 of the LysB endolysin sequence. The procedure was performed following the QuickChange II Site-Directed Mutagenesis Kit Manual (Agilent Technologies, Santa Clara, CA, USA), using mutagenic primers listed in 
Table S1. The presence of the correct substitution in all constructs was confirmed by DNA sequencing. The recombinant plasmids carrying the mutated lys $B$ gene were introduced into E. coli Tuner(DE3) by chemical transformation. Plasmids constructed in this study were deposited in the Collection of Plasmids and Microorganisms, KPD, University of Gdansk, Gdansk, Poland.

\subsection{Expression and Purification of LysB Endolysin and Its Substitution Variants}

E. coli Tuner(DE3) cells, harboring plasmid pET15b_LysB or its mutated versions, were grown in LB medium at $37^{\circ} \mathrm{C}$ supplemented with ampicillin to an optical density $\left(\mathrm{OD}_{600}\right)=0.5$. Production of recombinant proteins was induced by adding isopropyl- $\beta$-Dthiogalactopyranoside (IPTG) to a final concentration of $1 \mu \mathrm{M}$. In preliminary experiments, production was carried out either overnight at $18^{\circ} \mathrm{C}$ or for $4 \mathrm{~h}$ at $30^{\circ} \mathrm{C}$ or $37^{\circ} \mathrm{C}$. Overnight induction at $18^{\circ} \mathrm{C}$, optimal for recombinant protein production, has been chosen for further analyses. Next, bacteria were harvested by centrifugation $\left(10,000 \times \mathrm{g}, 20 \mathrm{~min}, 4^{\circ} \mathrm{C}\right)$ and suspended in $20 \mathrm{~mL}$ of NPi buffer $\left(50 \mathrm{mM} \mathrm{NaH}_{2} \mathrm{PO}_{4}, \mathrm{pH} 8.0,300 \mathrm{mM} \mathrm{NaCl}, 10 \mathrm{mM}\right.$ imidazole, $2 \mathrm{mM}$ 2-mercaptoethanol, $0.1 \%$ Triton X-100, 10\% ( $v / v)$ glycerol, and $1 \mathrm{mM}$ phenylmethylsulfonyl fluoride [PMSF]). Bacteria were disrupted by sonication (30 bursts of $10 \mathrm{~s}$ at an amplitude of $12 \mu \mathrm{m}$ ), and after centrifugation, the clear lysate was mixed with $4 \mathrm{~mL}$ TALON cobalt metal affinity resin (TAKARA Bio). The suspension was incubated on ice for $20 \mathrm{~min}$ with gentle shaking, and the purification procedure was continued according to the manufacturer's recommendations. The resin was washed with NPi buffer containing $10 \mathrm{mM}$ and $20 \mathrm{mM}$ imidazole, respectively. Elution was conducted with $150 \mathrm{mM}$ imidazole in NPi buffer. The purified proteins were dialyzed overnight into the storage buffer $(25 \mathrm{mM}$ potassium phosphate buffer (KPi), $\mathrm{pH} 8.0,50 \mathrm{mM} \mathrm{KCl}, 0.1 \%$ Triton X-100, and $60 \%$ glycerol) and kept at $-20{ }^{\circ} \mathrm{C}$ until further use. Bradford assay was applied to determine protein concentration.

\subsection{Isothermal Titration Calorimetry}

All ITC experiments were performed at $25^{\circ} \mathrm{C}$ using the AutoITC isothermal titration calorimeter (MicroCal Inc. GE Healthcare, Northampton, MA, USA). The details of the measuring devices and experimental setup were described previously [65]. The reagents, namely LTA of $S$. aureus (Sigma-Aldrich, St. Louis, MO, USA) and LysB, were dissolved directly in buffer consisting of $20 \mathrm{mM}$ potassium phosphate buffer, $\mathrm{pH} 8.0,10 \%$ glycerol. The experiment consisted of injecting $10.02 \mu \mathrm{L}$ ( 29 injections, $2 \mu \mathrm{L}$ for the first injection only) of $0.5 \mathrm{mM}$ buffered solution of LTA into the reaction cell, which initially contained $0.03 \mathrm{mM}$ buffered solution of LysB. A background titration, consisting of an identical titrant solution but with the buffer solution in the reaction cell only, was removed from each experimental titration. The LTA solution was injected at 4 min intervals. Each injection lasted $20 \mathrm{~s}$. The stirrer speed was kept constant at $300 \times \mathrm{rpm}$. The $\mathrm{CaCl}_{2}$-EDTA titration was performed to check the apparatus, and the results (stoichiometry, $K, \Delta H$ ) were compared with those obtained for the same samples (a test kit) at Malvern Instruments Ltd. (Malvern, UK).

\subsection{Testing the LysB Endolysin Optimum}

For substrate preparation, C. sporogenes ATCC 7955 cells were cultivated in TSB at $37^{\circ} \mathrm{C}$ in an anaerobic chamber (DG250 Workstation; Don Whitley Scientific Ltd., Bingley, West Yorkshire, UK) in a volume of $1 \mathrm{~L}$ until the mid-log phase was reached $\left(\mathrm{OD}_{600}\right.$ between 0.4 and 0.5 ). The cells were centrifuged, washed, and suspended in $100 \mathrm{~mL}$ of $0.85 \% \mathrm{NaCl}$. Before performing the tests, bacteria were suspended in $20 \mathrm{mM}$ 2-morpholinoethanesulfonic acid (MES-NaOH), $\mathrm{pH}$ 6.0, to reach the optical density $\left(\mathrm{OD}_{600}\right)$ of 0.7-1.0. The reaction mixtures contained $190 \mu \mathrm{L}$ of $C$. sporogenes ATCC 7955 cells and $10 \mu \mathrm{L}$ of LysB endolysin at a final concentration of $50 \mu \mathrm{g} / \mathrm{mL}$. Tests were performed in a 96-well plate format by measuring the $\mathrm{OD}_{600}$ of the suspension after $3 \mathrm{~h}$ incubation at $25^{\circ} \mathrm{C}$ (or temperatures ranging from 10 to $70^{\circ} \mathrm{C}$, when indicated) with the use of EnSpire multimode plate reader (Perkin Elmer, Waltham, MA, USA). The negative control contained $10 \mu \mathrm{L}$ of $20 \mathrm{mM}$ MES-NaOH 
pH 6.0 instead of LysB endolysin. All assays were conducted in triplicate. The lytic activity of LysB was calculated as follows: $\left(\Delta \mathrm{OD}_{600}\right.$ sample (endolysin added) $-\Delta \mathrm{OD}_{600}$ (buffer only))/initial $\mathrm{OD}_{600}[29]$.

To evaluate the effect of $\mathrm{pH}$ on lytic activity, the substrate C. sporogenes ATCC 7955 was suspended in: $20 \mathrm{mM}$ sodium acetate, $\mathrm{pH}$ 4.0; $20 \mathrm{mM}$ sodium acetate, $\mathrm{pH}$ 5.0; $20 \mathrm{mM}$ MES$\mathrm{NaOH}, \mathrm{pH} 6.0$ and pH 6.5; $20 \mathrm{mM} \mathrm{KPi}$, pH 7.0; and $20 \mathrm{mM}$ Tris-HCl, pH 7.5 of $\mathrm{OD}_{600}=1.0$. The effect of ionic strength on the lytic activity of LysB endolysin was evaluated with the addition of different concentrations of $\mathrm{NaCl}(0-300 \mathrm{mM})$ or different concentrations of buffer MES-NaOH, pH $6.0(10-100 \mathrm{mM})$. The influence of $\mathrm{Zn}^{2+}$ ions on the lytic activity of LysB was tested as described previously [29]. The minor changes were the incubation of the protein with EDTA at $30^{\circ} \mathrm{C}$ and usage of $20 \mathrm{mM}$ MES-NaOH, $\mathrm{pH}$ 6.0, as a reaction buffer.

\subsection{Antibacterial Spectrum of LysB Endolysin}

A zymogram assay for detection of bacteriolytic activity was carried out as described previously [66]. Briefly, $5 \mu \mathrm{g}$ of LysB endolysin and bovine serum albumin (BSA), which served as a negative control, were mixed with $2 \times$ Laemmli buffer $(125 \mathrm{mM}$ Tris- $\mathrm{HCl}, \mathrm{pH}$ 6.8; 5\% SDS; $10 \%$ 2-mercaptoethanol; $20 \%$ glycerol; and $0.02 \%$ bromophenol blue) and loaded on a $12.5 \%$ SDS-polyacrylamide gel containing $0.2 \%(w t / v)$ of bacteria (C. sporogenes ATCC 7955, C. intestinale ATCC 49213, B. cereus ATCC 13061, B. megaterium ATCC 14581, B. mycoides KPD 15, B. thuringensis KPD 114, S. aureus ATCC 25923, D. radiodurans ATCC 13939, E. coli MG1655, M. luteus ATCC 7468, S. enterica serovar Panama KPD 101, and T. flavus MAT1087). After electrophoresis, gels were washed for $30 \mathrm{~min}$ in distilled water at room temperature. Then, they were transferred to renaturation buffer $(20 \mathrm{mM}$ MES$\mathrm{NaOH}, \mathrm{pH} 6.0$, and $0.1 \%$ Triton $\mathrm{X}-100$ ) and incubated with gentle shaking for $16 \mathrm{~h}$ at $37^{\circ} \mathrm{C}$. Subsequently, gels were washed with distilled water, stained with $1 \%$ methylene blue in $0.01 \% \mathrm{KOH}$ for $2 \mathrm{~h}$, and destained with distilled water. The lytic activities appeared as white bands on the dark background.

Turbidity reduction assay (TRA) was used to characterize endolysin activity in a solution using the previously described method with some modifications [67]. For this assay, C. perfringens $(\mathrm{Cp})$ cultures were grown anaerobically at $37^{\circ} \mathrm{C}$ to mid-log phase in BYC medium. Next, the cells were centrifuged, washed three times with sterile distilled water, and resuspended in water to $\mathrm{OD}_{600}$ of $\sim 2.0$. The assay was run in a 96-well plate with $100 \mu \mathrm{L}$ of enzyme plus $100 \mu \mathrm{L}$ of cells mixed in one well, resulting in a starting $\mathrm{OD}_{600}$ of $\sim 1.0$ for the reaction. The 96-well plate was read in a SpectraMax 340 plate reader (Molecular Devices, LCC, San Jose, CA, USA), with the plate read every $20 \mathrm{~s}$ at $22{ }^{\circ} \mathrm{C}$ for $30 \mathrm{~min}$. The data were collected and analyzed using SoftMax Pro software (Molecular Devices, LCC, San Jose, CA, USA). LysB enzyme in elution buffer (NPi buffer with $150 \mathrm{mM}$ imidazole) was diluted from a stock concentration of $0.8 \mathrm{mg} / \mathrm{mL}$ into the respective assay buffer (25 mM Tris-HCl, pH 8.0; 20 mM KPi buffer, pH 7.5; or 20 mM MES-NaOH, pH 6.0) to make $0.2 \mathrm{mg} / \mathrm{mL}$ of the enzyme. When added to an equal volume of cells in water, the final concentration of LysB was $0.1 \mathrm{mg} / \mathrm{mL}$ in the assay.

\subsection{Size-Exclusion Chromatography (SEC) and Analytical Ultracentrifugation (AUC)}

SEC analyses were performed using a Superdex 75 10/300 GL column on an AKTA pure 25 chromatography system (GE Healthcare). The column was equilibrated with a buffer consisting of $25 \mathrm{mM} \mathrm{NaH}{ }_{2} \mathrm{PO}_{4}$ and $150 \mathrm{mM} \mathrm{NaCl}, \mathrm{pH}$ 8.0, and loaded with $300 \mu \mathrm{L}$ of LysB endolysin $(3 \mathrm{mg} / \mathrm{mL})$. The flow rate was set to $0.8 \mathrm{~mL} / \mathrm{min}$, and the absorbance was measured at $280 \mathrm{~nm}$ (mAU, milli-absorbance units). As a reference, the column was loaded with $300 \mu \mathrm{L}$ of dextran blue, $2 \mathrm{mg} / \mathrm{mL}(2000 \mathrm{kDa})$; bovine serum albumin, $5 \mathrm{mg} / \mathrm{mL}$ (66 kDa); trypsin inhibitor, $2 \mathrm{mg} / \mathrm{mL}(20 \mathrm{kDa})$; cytochrome C, $2 \mathrm{mg} / \mathrm{mL}(12.4 \mathrm{kDa})$; and aprotinin, $3 \mathrm{mg} / \mathrm{mL}(6.5 \mathrm{kDa})$.

Sedimentation velocity experiments were performed in a ProteomeLab XL-I analytical ultracentrifuge (Beckman-Coulter, Inc., Brea, CA, USA), equipped with AN 60Ti 4-hole rotor, $12 \mathrm{~mm}$ path length, and double-sector charcoal-epon cells, and loaded with $400 \mu \mathrm{L}$ 
of LysB ( $3 \mathrm{mg} / \mathrm{mL})$ and $410 \mu \mathrm{L}$ of buffer ( $25 \mathrm{mM} \mathrm{KPi}$ buffer, pH 8.0, $50 \mathrm{mM} \mathrm{KCl})$. The experiments were carried out at $20^{\circ} \mathrm{C}$ and $50,000 \times \mathrm{rpm}$, using continuous scan mode and radial spacing of $0.003 \mathrm{~cm}$. Scans were collected in 4 min intervals at $280 \mathrm{~nm}$. The fitting of absorbance versus cell radius data was performed using SEDFIT software, version 16.1 [68], and the continuous sedimentation coefficient distribution c(s) model, covering the range of $0-10 \mathrm{~S}$. The confidence level (F-ratio) was specified to 0.68 . The frictional ratio parameter $\mathrm{f} / \mathrm{f} 0=1.47$ was calculated as part of the non-linear regression fit. Biophysical parameters of the buffer, density $(1.00825 \mathrm{~g} / \mathrm{mL})$, and viscosity $(0.01018 \mathrm{P})$ at $20^{\circ} \mathrm{C}$ were measured using Anton Paar DMA 5000 density meter and Lovis 2000 ME viscometer. Proteins' partial specific volumes (V-bars) were estimated using SEDNTERP software (version 1.09, http:/ / www.jphilo.mailway.com/download.htm; accessed on 25 May 2021). The results were plotted using the GUSSI program (version 1.4.1, Chad Brautigam, http: / / biophysics.swmed.edu/MBR/software.html; accessed on 25 May 2021).

\subsection{Transmission Electron Microscopy}

The C. sporogenes ATCC 7955 cells were cultivated in $10 \mathrm{~mL}$ of TSB at $37^{\circ} \mathrm{C}$ under anaerobic conditions until an exponential growth phase was reached. The cells were centrifuged, washed, and resuspended in $20 \mathrm{mM}$ MES- $\mathrm{NaOH}, \mathrm{pH} 6.0$, to reach $\sim 10^{7}$ cells in a volume of $500 \mu \mathrm{L}$. The bacteria were incubated under anaerobic conditions at $37^{\circ} \mathrm{C}$ for $20 \mathrm{~min}$ with LysB endolysin at a final concentration of $50 \mu \mathrm{g} / \mathrm{mL}$. The negative control contained buffer ( $25 \mathrm{mM}$ MES-NaOH, pH 6.0) instead of the LysB endolysin. Bacteria were washed twice with PBS; then, the pellet was fixed with 2.5\% glutaraldehyde (Polysciences Inc., Warrington, PA, USA) and post-fixed with 1\% osmium tetroxide (Polysciences Inc.). Bacteria were dehydrated with ethanol and embedded in Epon 812 resin (Sigma-Aldrich, St. Louis, MO, USA) Ultrathin sections were prepared with Leica UC7 ultramicrotome $(60 \mathrm{~nm})$. Sections were stained with lead citrate and uranyl acetate. Bacterial cells were studied at $120 \mathrm{kV}$ using the Tecnai Spirit BioTWIN electron microscope (FEI Company, Hillsboro, OR, USA).

Supplementary Materials: The following are available online at https:/ /www.mdpi.com/article/10 .3390/ijms22179536/s1: Table S1: Sequences of PCR primers used in this study; Table S2: Analysis of the part of genome C. botulinum E3 strain Alaska E43 by the prophage prediction program PHASTER; Table S3: Summary of lytic activity of LysB endolysin against representative bacterial strains; Supplementary File S1: Protein amino acid sequences and their respective GenBank or PDB accessions numbers; Supplementary File S2: BLAST results for Circoletto analysis.

Author Contributions: Conceptualization, M.P., A.-K.K. and T.K.; methodology, A.M., M.P., M.S. and D.W.; software, L.P.K.; validation, T.K., J.M. and D.M.D.; formal analysis, M.P., J.M., D.M.D., S.M.S. and T.K.; investigation, A.M., M.P., D.W., S.M.S. and J.J.W.; resources, T.K.; data curation, A.-K.K. and L.P.K.; writing—original draft preparation, A.M. and M.P.; writing—review and editing, A.-K.K., T.K. and D.M.D.; visualization, A.M., M.P. and S.M.S.; supervision, T.K.; project administration, T.K.; funding acquisition, T.K. All authors have read and agreed to the published version of the manuscript.

Funding: This research was funded by the European Union's Horizon 2020 Research and Innovation Programme Virus-X project: Viral Metagenomics for Innovation Value (grant no. 685778) through T.K; Approval date 18 November 2015.

Data Availability Statement: The files related to the bioinformatics analysis are available at: https:/ / doi.org/10.18150/NMEJQ6.

Conflicts of Interest: The authors declare no conflict of interest.

\section{References}

1. Shukla, H.D.; Sharma, S.K. Clostridium botulinum: A bug with beauty and weapon. Crit. Rev. Microbiol. 2005, 31, 11-18. [CrossRef]

2. Poulain, B.; Popoff, M.R. Why Are Botulinum Neurotoxin-Producing Bacteria So Diverse and Botulinum Neurotoxins So Toxic? Toxins 2019, 11, 34. [CrossRef]

3. Sobel, J. Botulism. Clin. Infect. Dis. 2005, 41, 1167-1173. [CrossRef] 
4. Mazuet, C.; Legeay, C.; Sautereau, J.; Ma, L.; Bouchier, C.; Bouvet, P.; Popoff, M.R. Diversity of Group I and II Clostridium botulinum Strains from France Including Recently Identified Subtypes. Genome Biol. Evol. 2016, 8, 1643-1660. [CrossRef]

5. Lonati, D.; Schicchi, A.; Crevani, M.; Buscaglia, E.; Scaravaggi, G.; Maida, F.; Cirronis, M.; Petrolini, V.M.; Locatelli, C.A. Foodborne Botulism: Clinical Diagnosis and Medical Treatment. Toxins 2020, 12, 509. [CrossRef]

6. Carter, A.T.; Peck, M.W. Genomes, neurotoxins and biology of Clostridium botulinum Group I and Group II. Res. Microbiol. 2015, 166, 303-317. [CrossRef]

7. Brunt, J.; van Vliet, A.H.M.; Stringer, S.C.; Carter, A.T.; Lindström, M.; Peck, M.W. Pan-Genomic Analysis of Clostridium botulinum Group II (Non-Proteolytic, C. botulinum) Associated with Foodborne Botulism and Isolated from the Environment. Toxins 2020, 12, 306. [CrossRef]

8. Skarin, H.; Håfström, T.; Westerberg, J.; Segerman, B. Clostridium botulinum group III: A group with dual identity shaped by plasmids, phages and mobile elements. BMC Genom. 2011, 12, 185. [CrossRef] [PubMed]

9. Miyashita, S.I.; Zhang, J.; Zhang, S.; Shoemaker, C.B.; Dong, M. Delivery of single-domain antibodies into neurons using a chimeric toxin-based platform is therapeutic in mouse models of botulism. Sci. Transl. Med. 2021, 13. [CrossRef] [PubMed]

10. Servick, K. Decoy toxin harnessed to fight botulism. Science 2021, 371, 113-114. [CrossRef] [PubMed]

11. Cho, J.H.; Kwon, J.G.; O'Sullivan, D.J.; Ryu, S.; Lee, J.H. Development of an endolysin enzyme and its cell wall-binding domain protein and their applications for biocontrol and rapid detection of Clostridium perfringens in food. Food Chem. 2021, 345, 128562. [CrossRef]

12. Hammond, R.W.; Swift, S.M.; Foster-Frey, J.A.; Kovalskaya, N.Y.; Donovan, D.M. Optimized production of a biologically active Clostridium perfringens glycosyl hydrolase phage endolysin PlyCP41 in plants using virus-based systemic expression. BMC Biotechnol. 2019, 19, 101. [CrossRef]

13. Zimmer, M.; Vukov, N.; Scherer, S.; Loessner, M.J. The murein hydrolase of the bacteriophage phi3626 dual lysis system is active against all tested Clostridium perfringens strains. Appl. Environ. Microbiol. 2002, 68, 5311-5317. [CrossRef]

14. Simmons, M.; Donovan, D.M.; Siragusa, G.R.; Seal, B.S. Recombinant expression of two bacteriophage proteins that lyse Clostridium perfringens and share identical sequences in the $C$-terminal cell wall binding domain of the molecules but are dissimilar in their $N$-terminal active domains. J. Agric. Food Chem. 2010, 58, 10330-10337. [CrossRef]

15. Nariya, H.; Miyata, S.; Tamai, E.; Sekiya, H.; Maki, J.; Okabe, A. Identification and characterization of a putative endolysin encoded by episomal phage phiSM101 of Clostridium perfringens. Appl. Microbiol. Biotechnol. 2011, 90, 1973-1979. [CrossRef]

16. Schmitz, J.E.; Ossiprandi, M.C.; Rumah, K.R.; Fischetti, V.A. Lytic enzyme discovery through multigenomic sequence analysis in Clostridium perfringens. Appl. Microbiol. Biotechnol. 2011, 89, 1783-1795. [CrossRef] [PubMed]

17. Gervasi, T.; Horn, N.; Wegmann, U.; Dugo, G.; Narbad, A.; Mayer, M.J. Expression and delivery of an endolysin to combat Clostridium perfringens. Appl. Microbiol. Biotechnol. 2014, 98, 2495-2505. [CrossRef] [PubMed]

18. Ha, E.; Son, B.; Ryu, S. Clostridium perfringens Virulent Bacteriophage CPS2 and Its Thermostable Endolysin LysCPS2. Viruses 2018, 10, 251. [CrossRef] [PubMed]

19. Ritter, S.C.; Hackel, B.J. Validation and Stabilization of a Prophage Lysin of Clostridium perfringens by Using Yeast Surface Display and Coevolutionary Models. Appl. Environ. Microbiol. 2019, 85, e00054-19. [CrossRef]

20. Mondal, S.I.; Draper, L.A.; Ross, R.P.; Hill, C. Bacteriophage endolysins as a potential weapon to combat Clostridioides difficile infection. Gut Microbes 2020, 12, 1813533. [CrossRef] [PubMed]

21. Wang, Q.; Euler, C.W.; Delaune, A.; Fischetti, V.A. Using a Novel Lysin To Help Control Clostridium difficile Infections. Antimicrob. Agents Chemother. 2015, 59, 7447-7457. [CrossRef] [PubMed]

22. Mayer, M.J.; Narbad, A.; Gasson, M.J. Molecular characterization of a Clostridium difficile bacteriophage and its cloned biologically active endolysin. J. Bacteriol. 2008, 190, 6734-6740. [CrossRef] [PubMed]

23. Mayer, M.J.; Gasson, M.J.; Narbad, A. Genomic sequence of bacteriophage ATCC 8074-B1 and activity of its endolysin and engineered variants against Clostridium sporogenes. Appl. Environ. Microbiol. 2012, 78, 3685-3692. [CrossRef] [PubMed]

24. Mayer, M.J.; Payne, J.; Gasson, M.J.; Narbad, A. Genomic sequence and characterization of the virulent bacteriophage phiCTP1 from Clostridium tyrobutyricum and heterologous expression of its endolysin. Appl. Environ. Microbiol. 2010, 76, 5415-5422. [CrossRef] [PubMed]

25. Zhang, Z.; Lahti, M.; Douillard, F.P.; Korkeala, H.; Lindström, M. Phage lysin that specifically eliminates Clostridium botulinum Group I cells. Sci. Rep. 2020, 10, 21571. [CrossRef] [PubMed]

26. Mayer, M.J.; Garefalaki, V.; Spoerl, R.; Narbad, A.; Meijers, R. Structure-based modification of a Clostridium difficile-targeting endolysin affects activity and host range. J. Bacteriol. 2011, 193, 5477-5486. [CrossRef]

27. Dunne, M.; Leicht, S.; Krichel, B.; Mertens, H.D.; Thompson, A.; Krijgsveld, J.; Svergun, D.I.; Gómez-Torres, N.; Garde, S.; Uetrecht, C.; et al. Crystal Structure of the CTP1L Endolysin Reveals How Its Activity Is Regulated by a Secondary Translation Product. J. Biol. Chem. 2016, 291, 4882-4893. [CrossRef]

28. Plotka, M.; Kaczorowska, A.K.; Stefanska, A.; Morzywolek, A.; Fridjonsson, O.H.; Dunin-Horkawicz, S.; Kozlowski, L.; Hreggvidsson, G.O.; Kristjansson, J.K.; Dabrowski, S.; et al. Novel highly thermostable endolysin from Thermus scotoductus MAT2119 bacteriophage Ph2119 with amino acid sequence similarity to eukaryotic peptidoglycan recognition proteins. Appl. Environ. Microbiol. 2014, 80, 886-895. [CrossRef] 
29. Plotka, M.; Kaczorowska, A.K.; Morzywolek, A.; Makowska, J.; Kozlowski, L.P.; Thorisdottir, A.; Skírnisdottir, S.; Hjörleifsdottir, S.; Fridjonsson, O.H.; Hreggvidsson, G.O.; et al. Biochemical Characterization and Validation of a Catalytic Site of a Highly Thermostable Ts2631 Endolysin from the Thermus scotoductus Phage vB_Tsc2631. PLoS ONE 2015, 10, e0137374. [CrossRef]

30. Aevarsson, A.; Kaczorowska, A.K.; Adalsteinsson, B.T.; Ahlqvist, J.; Al-Karadaghi, S.; Altenbuchner, J.; Arsin, H.; Átlasson, Ú.; Brandt, D.; Cichowicz-Cieślak, M.; et al. Going to extremes-a metagenomic journey into the dark matter of life. FEMS Microbiol. Lett. 2021, 368, fnab067. [CrossRef]

31. Plotka, M.; Kapusta, M.; Dorawa, S.; Kaczorowska, A.K.; Kaczorowski, T. Ts2631 Endolysin from the Extremophilic Thermus scotoductus Bacteriophage vB_Tsc2631 as an Antimicrobial Agent against Gram-Negative Multidrug-Resistant Bacteria. Viruses 2019, 11, 657. [CrossRef] [PubMed]

32. Tacconelli, E.; Carrara, E.; Savoldi, A.; Harbarth, S.; Mendelson, M.; Monnet, D.L.; Pulcini, C.; Kahlmeter, G.; Kluytmans, J.; Carmeli, Y.; et al. Discovery, research, and development of new antibiotics: The WHO priority list of antibiotic-resistant bacteria and tuberculosis. Lancet Infect. Dis. 2018, 18, 318-327. [CrossRef]

33. Darzentas, N. Circoletto: Visualizing sequence similarity with Circos. Bioinformatics 2010, 26, 2620-2621. [CrossRef] [PubMed]

34. Bhardwaj, T.; Haque, S.; Somvanshi, P. Comparative assessment of the therapeutic drug targets of C. botulinum ATCC 3502 and C. difficile str. 630 using in silico subtractive proteomics approach. J. Cell. Biochem. 2019, 120, 16160-16184. [CrossRef]

35. Weigand, M.R.; Pena-Gonzalez, A.; Shirey, T.B.; Broeker, R.G.; Ishaq, M.K.; Konstantinidis, K.T.; Raphael, B.H. Implications of Genome-Based Discrimination between Clostridium botulinum Group I and Clostridium sporogenes Strains for Bacterial Taxonomy. Appl. Environ. Microbiol. 2015, 81, 5420-5429. [CrossRef] [PubMed]

36. Loeffler, J.M.; Nelson, D.; Fischetti, V.A. Rapid killing of Streptococcus pneumoniae with a bacteriophage cell wall hydrolase. Science 2001, 294, 2170-2172. [CrossRef]

37. Schmelcher, M.; Donovan, D.M.; Loessner, M.J. Bacteriophage endolysins as novel antimicrobials. Future Microbiol. 2012, 7, 1147-1171. [CrossRef] [PubMed]

38. Brüssow, H.; Desiere, F. Comparative phage genomics and the evolution of Siphoviridae: Insights from dairy phages. Mol. Microbiol. 2001, 39, 213-222. [CrossRef]

39. Proux, C.; van Sinderen, D.; Suarez, J.; Garcia, P.; Ladero, V.; Fitzgerald, G.F.; Desiere, F.; Brüssow, H. The dilemma of phage taxonomy illustrated by comparative genomics of Sfi21-like Siphoviridae in lactic acid bacteria. J. Bacteriol. 2002, 184, 6026-6036. [CrossRef]

40. Canchaya, C.; Proux, C.; Fournous, G.; Bruttin, A.; Brüssow, H. Prophage genomics. Microbiol. Mol. Biol. Rev. 2003, 67, 238-276. [CrossRef]

41. Lu, S.; Wang, J.; Chitsaz, F.; Derbyshire, M.K.; Geer, R.C.; Gonzales, N.R.; Gwadz, M.; Hurwitz, D.I.; Marchler, G.H.; Song, J.S.; et al. CDD/SPARCLE: The conserved domain database in 2020. Nucleic Acids Res. 2019, 48, D265-D268. [CrossRef]

42. El-Gebali, S.; Mistry, J.; Bateman, A.; Eddy, S.R.; Luciani, A.; Potter, S.C.; Qureshi, M.; Richardson, L.J.; Salazar, G.A.; Smart, A.; et al. The Pfam protein families database in 2019. Nucleic Acids Res. 2019, 47, D427-D432. [CrossRef]

43. Cheng, X.; Zhang, X.; Pflugrath, J.W.; Studier, F.W. The structure of bacteriophage T7 lysozyme, a zinc amidase and an inhibitor of T7 RNA polymerase. Proc. Natl. Acad. Sci. USA 1994, 91, 4034-4038. [CrossRef] [PubMed]

44. Dziarski, R.; Kashyap, D.R.; Gupta, D. Mammalian peptidoglycan recognition proteins kill bacteria by activating two-component systems and modulate microbiome and inflammation. Microb. Drug Resist. 2012, 18, 280-285. [CrossRef]

45. Sharma, P.; Dube, D.; Singh, A.; Mishra, B.; Singh, N.; Sinha, M.; Dey, S.; Kaur, P.; Mitra, D.K.; Sharma, S.; et al. Structural basis of recognition of pathogen-associated molecular patterns and inhibition of proinflammatory cytokines by camel peptidoglycan recognition protein. J. Biol. Chem. 2011, 286, 16208-16217. [CrossRef] [PubMed]

46. Eugster, M.R.; Haug, M.C.; Huwiler, S.G.; Loessner, M.J. The cell wall binding domain of Listeria bacteriophage endolysin PlyP35 recognizes terminal GlcNAc residues in cell wall teichoic acid. Mol. Microbiol. 2011, 81, 1419-1432. [CrossRef] [PubMed]

47. Kim, M.S.; Byun, M.; Oh, B.H. Crystal structure of peptidoglycan recognition protein LB from Drosophila melanogaster. Nat. Immunol. 2003, 4, 787-793. [CrossRef]

48. Ugorcakova, J.; Bukovska, G. Lysins and Holins: Tools of Phage-Induced Lysis. Biologia 2003, 58, 327-334. [CrossRef]

49. Volozhantsev, N.V.; Oakley, B.B.; Morales, C.A.; Verevkin, V.V.; Bannov, V.A.; Krasilnikova, V.M.; Popova, A.V.; Zhilenkov, E.L.; Garrish, J.K.; Schegg, K.M.; et al. Molecular characterization of podoviral bacteriophages virulent for Clostridium perfringens and their comparison with members of the Picovirinae. PLoS ONE 2012, 7, e38283. [CrossRef]

50. Mehta, K.K.; Paskaleva, E.E.; Wu, X.; Grover, N.; Mundra, R.V.; Chen, K.; Zhang, Y.; Yang, Z.; Feng, H.; Dordick, J.S.; et al. Newly identified bacteriolytic enzymes that target a wide range of clinical isolates of Clostridium difficile. Biotechnol. Bioeng. 2016, 113, 2568-2576. [CrossRef]

51. Peck, M.W.; Stringer, S.C. The safety of pasteurised in-pack chilled meat products with respect to the foodborne botulism hazard. Meat Sci. 2005, 70, 461-475. [CrossRef]

52. Swift, S.M.; Waters, J.J.; Rowley, D.T.; Oakley, B.B.; Donovan, D.M. Characterization of two glycosyl hydrolases, putative prophage endolysins, that target Clostridium perfringens. FEMS Microbiol. Lett. 2018, 365. [CrossRef] [PubMed]

53. Swift, S.M.; Seal, B.S.; Garrish, J.K.; Oakley, B.B.; Hiett, K.; Yeh, H.Y.; Woolsey, R.; Schegg, K.M.; Line, J.E.; Donovan, D.M. A Thermophilic Phage Endolysin Fusion to a Clostridium perfringens-Specific Cell Wall Binding Domain Creates an Anti-Clostridium Antimicrobial with Improved Thermostability. Viruses 2015, 7, 3019-3034. [CrossRef] [PubMed] 
54. Briers, Y.; Lavigne, R. Breaking barriers: Expansion of the use of endolysins as novel antibacterials against Gram-negative bacteria. Future Microbiol. 2015, 10, 377-390. [CrossRef]

55. Plotka, M.; Sancho-Vaello, E.; Dorawa, S.; Kaczorowska, A.K.; Kozlowski, L.P.; Kaczorowski, T.; Zeth, K. Structure and function of the Ts2631 endolysin of Thermus scotoductus phage vB_Tsc2631 with unique $N$-terminal extension used for peptidoglycan binding. Sci. Rep. 2019, 9, 1261. [CrossRef]

56. Monterroso, B.; Sáiz, J.L.; García, P.; García, J.L.; Menéndez, M. Insights into the structure-function relationships of pneumococcal cell wall lysozymes, LytC and Cpl-1. J. Biol. Chem. 2008, 283, 28618-28628. [CrossRef] [PubMed]

57. Höltje, J.V.; Tomasz, A. Lipoteichoic acid: A specific inhibitor of autolysin activity in Pneumococcus. Proc. Natl. Acad. Sci. USA 1975, 72, 1690-1694. [CrossRef] [PubMed]

58. Sambrook, J.; Russell, D.W. Molecular cloning: A laboratory manual, 3rd ed.; Cold Spring Harbor Laboratory Press: Cold Spring Harbor, NY, USA, 2001.

59. Arndt, D.; Grant, J.R.; Marcu, A.; Sajed, T.; Pon, A.; Liang, Y.; Wishart, D.S. PHASTER: A better, faster version of the PHAST phage search tool. Nucleic Acids Res. 2016, 44, W16-W21. [CrossRef] [PubMed]

60. Sievers, F.; Wilm, A.; Dineen, D.; Gibson, T.J.; Karplus, K.; Li, W.; Lopez, R.; McWilliam, H.; Remmert, M.; Söding, J.; et al. Fast, scalable generation of high-quality protein multiple sequence alignments using Clustal Omega. Mol. Syst. Biol. 2011, 7, 539. [CrossRef] [PubMed]

61. Kozlowski, L.P. IPC-Isoelectric Point Calculator. Biol. Direct 2016, 11, 55. [CrossRef] [PubMed]

62. Roy, A.; Kucukural, A.; Zhang, Y. I-TASSER: A unified platform for automated protein structure and function prediction. Nat. Protoc. 2010, 5, 725-738. [CrossRef]

63. Shuvo, M.H.; Gulfam, M.; Bhattacharya, D. DeepRefiner: High-accuracy protein structure refinement by deep network calibration. Nucleic Acids Res. 2021, 49, W147-W152. [CrossRef] [PubMed]

64. Pettersen, E.F.; Goddard, T.D.; Huang, C.C.; Couch, G.S.; Greenblatt, D.M.; Meng, E.C.; Ferrin, T.E. UCSF Chimera-a visualization system for exploratory research and analysis. J. Comput. Chem. 2004, 25, 1605-1612. [CrossRef] [PubMed]

65. Panuszko, A.; Bruździak, P.; Zielkiewicz, J.; Wyrzykowski, D.; Stangret, J. Effects of urea and trimethylamine-N-oxide on the properties of water and the secondary structure of hen egg white lysozyme. J. Phys. Chem. B 2009, 113, 14797-14809. [CrossRef] [PubMed]

66. Plotka, M.; Szadkowska, M.; Håkansson, M.; Kovačič, R.; Al-Karadaghi, S.; Walse, B.; Werbowy, O.; Kaczorowska, A.K.; Kaczorowski, T. Molecular Characterization of a Novel Lytic Enzyme LysC from Clostridium intestinale URNW and Its Antibacterial Activity Mediated by Positively Charged N-Terminal Extension. Int. J. Mol. Sci. 2020, 21, 4894. [CrossRef]

67. Donovan, D.M.; Dong, S.; Garrett, W.; Rousseau, G.M.; Moineau, S.; Pritchard, D.G. Peptidoglycan hydrolase fusions maintain their parental specificities. Appl. Environ. Microbiol. 2006, 72, 2988-2996. [CrossRef] [PubMed]

68. Brown, P.H.; Schuck, P. A new adaptive grid-size algorithm for the simulation of sedimentation velocity profiles in analytical ultracentrifugation. Comput. Phys. Commun. 2008, 178, 105-120. [CrossRef] 